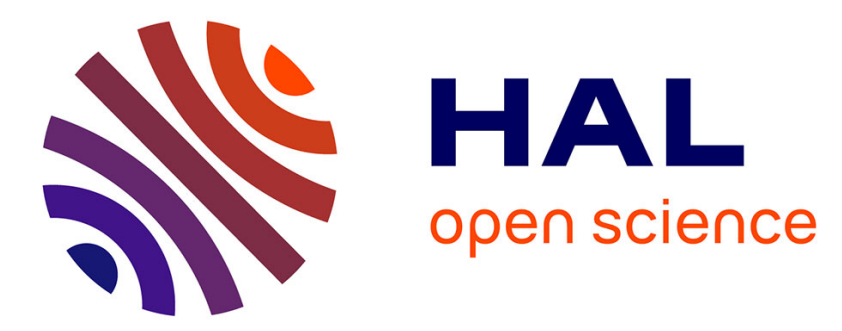

\title{
Candi Kimpulan (Central Java, Indonesia) Architecture and Consecration Rituals of a 9th-Century Hindu Temple
}

\author{
Indung Panca Putra, Ary Setyastuti, Subagyo Pramumijoyo, Agustijanto \\ Indrajaya, Agni Sesaria Mochtar, Véronique Degroot
}

\section{To cite this version:}

Indung Panca Putra, Ary Setyastuti, Subagyo Pramumijoyo, Agustijanto Indrajaya, Agni Sesaria Mochtar, et al.. Candi Kimpulan (Central Java, Indonesia) Architecture and Consecration Rituals of a 9th-Century Hindu Temple. Bulletin de l'Ecole française d'Extrême-Orient, 2020, 105, pp.73-114. hal-02934389

\section{HAL Id: hal-02934389 \\ https://hal.science/hal-02934389}

Submitted on 15 Sep 2020

HAL is a multi-disciplinary open access archive for the deposit and dissemination of scientific research documents, whether they are published or not. The documents may come from teaching and research institutions in France or abroad, or from public or private research centers.
L'archive ouverte pluridisciplinaire HAL, est destinée au dépôt et à la diffusion de documents scientifiques de niveau recherche, publiés ou non, émanant des établissements d'enseignement et de recherche français ou étrangers, des laboratoires publics ou privés. 


\title{
Candi Kimpulan (Central Java, Indonesia) \\ Architecture and Consecration Rituals of a 9th-Century Hindu Temple
}

\author{
Indung Panca Putra, Ary Setyastuti, Subagyo Pramumijoyo, \\ Agustijanto Indrajaya, Agni Sesaria Mochtar \& Véronique Degroot
}

\begin{abstract}
In December 2009, remains of a small Śiva sanctuary were found buried under several metres of volcanic material in the village of Kimpulan, on the southern slope of Mount Merapi. This discovery provides us with an unexpected glimpse into the architectural tradition and the ritual life of a 9th-century Javanese rural community. Not only is Kimpulan an exceptional example of mixed-materials architecture, but its relatively good state of preservation brings new clues to a recurring issue in Javanese archaeology: the function of secondary shrines in Śaiva context. The most remarkable find of the Kimpulan excavations certainly is the eighteen undisturbed ritual deposits discovered beneath the pavement and under the statues. This article presents and discusses these data, linking the Kimpulan deposits with two rituals known from Indian texts, namely the ratnanyāsa (installation of a statue/inga) and the garbhanyāsa (temple consecration).
\end{abstract}

Keywords: archaeology of religions; Hinduism; temple architecture; Śaiva rituals.

\section{Résumé}

En décembre 2009, les ruines d'un petit sanctuaire śivaïte ont été retrouvés enterrés sous plusieurs mètres de matériaux volcaniques dans la petite ville de Kimpulan, sur le flanc sud du mont Merapi. Cette découverte jette une lumière inattendue sur la tradition architecturale et la vie rituelle d'une communauté rurale dans la Java du $\mathrm{IX}^{e}$ siècle. Kimpulan est non seulement un exemple exceptionnel d'architecture en matériaux mixtes, mais son assez bon état de conservation apporte également de nouveaux éléments de réponse à un problème récurrent de l'archéologie javanaise: la fonction des sanctuaires secondaires en contexte sivaïte. La découverte la plus remarquable faite lors des fouilles de Kimpulan est certainement celle des dix-huit dépôts rituels intacts découverts sous le dallage et les statues. Cet article présente et discute ce matériel, et associe les dépôts de Kimpulan à deux rituels connus des textes indiens, à savoir le ratnanyāsa (installation d'une statue/linga) et le garbhanyāsa (consécration du temple).

Mots-clés : archéologie des religions; hindouisme; architecture religieuse; rituels śivaïtes. 



\title{
Candi Kimpulan (Central Java, Indonesia) \\ Architecture and Consecration Rituals of a 9th-Century Hindu Temple
}

\author{
Indung Panca Putra, Ary Setyastuti, Subagyo Pramumijoyo, \\ Agustijanto Indrajaya, Agni Sesaria Mochtar \& Véronique Degroot*
}

\section{Introduction $^{1}$}

On December the 11th 2009, building workers were digging the foundation for a new library on the campus of the Universitas Islam Indonesia (UII, Sleman, Yogyakarta) when they unearthed several dressed stones. Experts from the local office for cultural heritage preservation (Balai Pelestarian Cagar Budaya-BPCB) were called to the spot. A rapid survey concluded that a temple from the Hindu-Buddhist period stood buried under a layer of volcanic debris $2.7 \mathrm{~m}$ thick. ${ }^{2}$ The remains, momentarily called "Candi Pustakasala" were renamed "Candi Kimpulan", after the nearby hamlet. Following an agreement between the UII and the BPCB, the construction of the library was stopped and rescue excavations were undertaken. ${ }^{3}$ Two extremely well-preserved stone structures, surrounded by a low wall made of river stones, were discovered (fig. 1). Following the conclusions of a preliminary technical study, the BPCB decided to restore the temples,

\footnotetext{
* Indung Panca Putra, Balai Pelestarian Cagar Budaya Daerah Istimewa Yogyakarta - Office for cultural heritage preservation of the special province of Yogyakarta (BPCB Yogyakarta), Indungpanca@yahoo.com; Ary Setyastuti, BPCB Yogyakarta, bp3diy@yahoo.com; Subagyo Pramumijoyo, Universitas Gadjah Mada - Gadjah Mada University (UGM), Yogyakarta, jtg.ft@ugm.ac.id; Agustijanto Indrajaya, Pusat Penelitian Arkeologi Nasional - National Centre for Archaeological Research, agustijanto2004@yahoo.com; Agni Sesaria Mochtar, Balai arkeologi Yogyakarta - Yogyakarta Archaeological Office, agnimochtar@yahoo.co.id; Véronique Degroot, École française d'Extrême-Orient, Université Paris Sciences et Lettres (PSL), CASE/UMR 8170, veronique.degroot@efeo.net. The authors would like to thank Bruno Bruguier, Emmanuel Francis, Dominic Goodall, Arlo Griffiths and Charlotte Schmid for their kind advice on certain sections of this paper. The research for this article has been undertaken as part of the project DHARMA "The Domestication of 'Hindu' Asceticism and the Religious Making of South and Southeast Asia", funded by the European Research Council (ERC) under the European Union's Horizon 2020 research and innovation programme (grant agreement no. 809994). See https://dharma.hypotheses.org.

1. This paper is based on direct fieldwork observations of the authors. We must however mention that the excavation and restoration of Candi Kimpulan have already been the subject of a couple of Indonesian language publications. See Ari Setyastuti \& Indung Panca Putra 2011 and Balai Pelestarian Peninggalan Purbakala Yogyakarta n.d.

2. This measurement is taken from modern ground level to the top of the temple walls. The ancient ground level was actually located $c a .5 .5 \mathrm{~m}$ below the modern level.

3. A backhoe was used to dig the first $2 \mathrm{~m}$. A grid oriented to the cardinal points was laid on a surface of $24 \times 24 \mathrm{~m}$, each excavation square measuring $2 \times 2 \mathrm{~m}$. Sixty-four squares were fully or partially excavated, using the spit method. Each spit was $20 \mathrm{~cm}$ deep.
} 


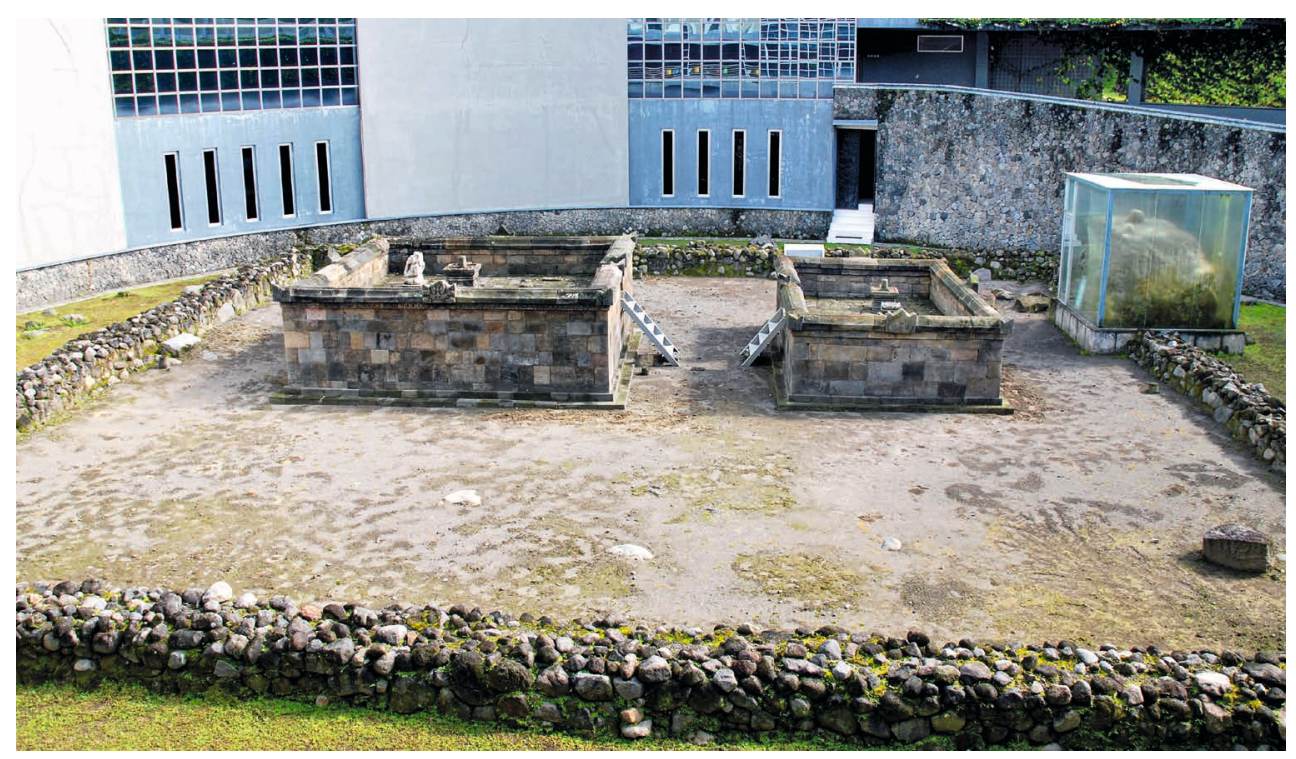

Fig. 1 - General view of Candi Kimpulan (photo: V. Degroot/EFEO).

whereupon pavements of both structures were dismantled in order to place a drainage system. ${ }^{4}$ It is during these restoration works that Candi Kimpulan yielded its long-kept secret: more than 18 undisturbed ritual deposits. ${ }^{5}$

\section{Localisation and surroundings}

Candi Kimpulan is located on the southern slope of Mt Merapi, at an elevation of $320 \mathrm{~m}$ above sea level (fig. 2). ${ }^{6}$ It is about $50 \mathrm{~m}$ to the west of the Kladuan river, which flows north-south in a bed cutting through $c a .8 \mathrm{~m}$ of volcanic materials. ${ }^{7}$ The land is of gentle incline ${ }^{8}$ and the area is covered with irrigated rice fields. Nowadays, a change in cultivation pattern occurs around the $600 \mathrm{~m}$ contour line, where wet-rice cultivation becomes difficult and is replaced by dry fields, market vegetables and trees.

4. The restoration was initially planned from September to December 2010. However, due to a massive eruption of Mt Merapi in October-November 2010, work temporarily stopped. It was resumed in December and continued until the end of January 2011.

5. The discovery was made by the BPCB DIY. Although the ritual deposits were excavated as carefully as possible, the staff of the BPCB DIY is composed of preservation specialists, not professional archaeologists. Therefore, some information is probably missing, in particular regarding possible ash and plant remains that the deposits might have contained. Indung Panca Putra was head of the restoration team and present during the whole process. Agni Mochtar and Véronique Degroot had the occasion to access the material and archives of the BPCB after the discovery had been made and the deposits had been transferred to the BPCB and to the UII Museum.

6. Its administrative localisation is dusun Kimpulan, desa Umbulmartani, kecamatan Ngemplak, kabupaten Sleman, Daearah Istimewa Yogyakarta. Its geographical coordinates are 741 '18.24”S, $110^{\circ} 24^{\prime} 55.19$ '"E (WGS 84).

7. Today the Kladuan (also spelled Klanduan) is a small river and its source is situated at rather low altitude ( $c a .500 \mathrm{~m}$ above sea level). In earlier times, it might however have been connected with the Kuning River, which flows $2 \mathrm{~km}$ to the east and is a major channel for lahar and flooding.

8. The slope is $c a .3 .5 \%$. 


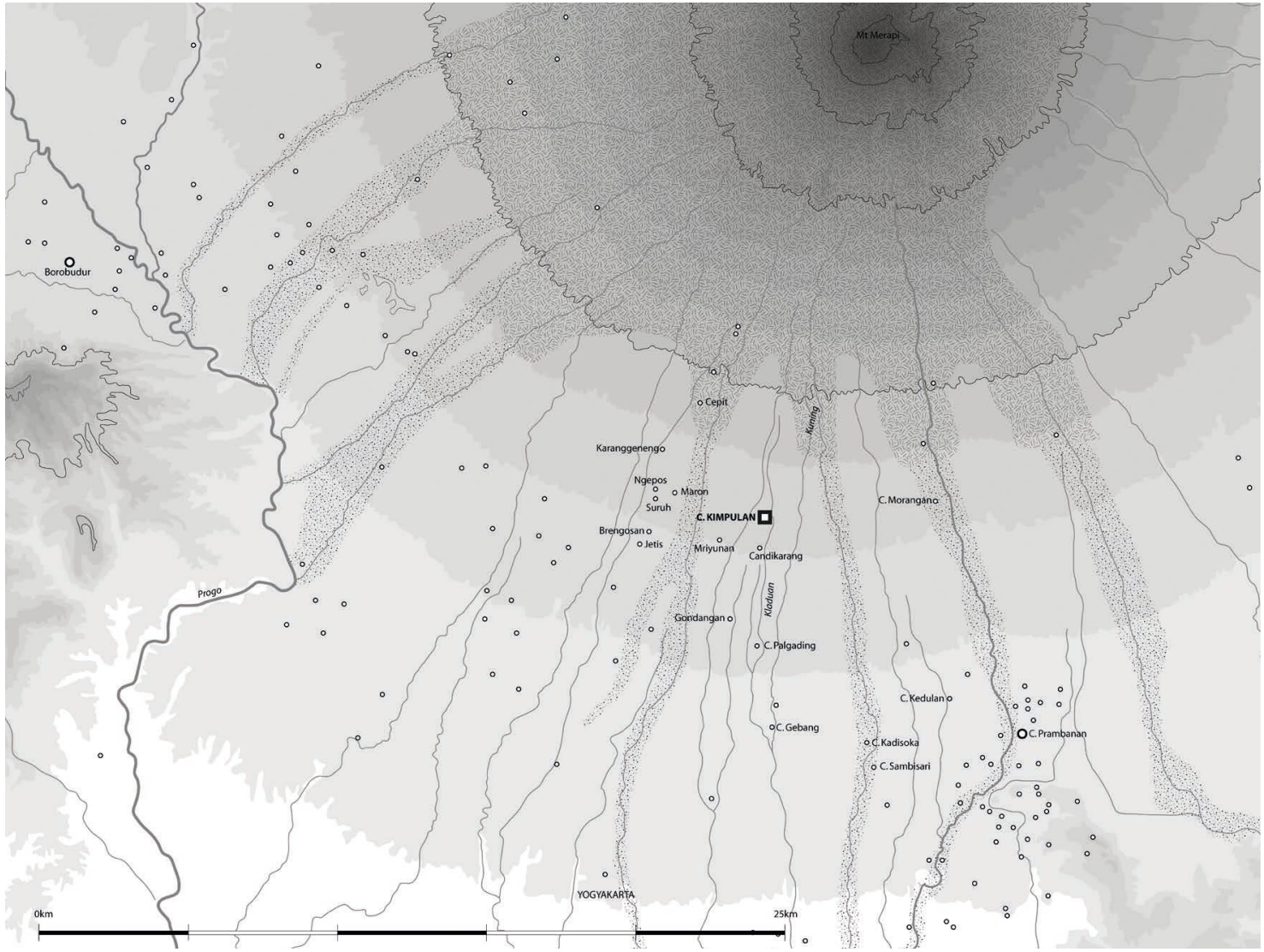

Fig. 2 - Situation map of Candi Kimpulan with localization of the main sites mentioned in the text and pyroclastic flow/lahar hazard prone areas (as of 1978). All dots are sites dated to the Hindu-Buddhist period (background map adapted from Pardyanto et al. 1978).

The closest Hindu-Buddhist buildings still standing are Candi Palgading and Morangan. ${ }^{9}$ Candi Morangan ${ }^{10}$ is a well-known Hindu sanctuary, while Palgading is the only Buddhist complex in the area. ${ }^{11}$ The surroundings of Candi Kimpulan have yielded many smaller remains: within a $5 \mathrm{~km}$ radius, one counts at least 10 sites where sculptures, yonis and/or temple stones have been discovered. ${ }^{12}$ Five of these sites have yielded Hindu material ${ }^{13}$ but, except for Palgading, no Buddhist remains have been formally identified.

9. Palgading is located $4.2 \mathrm{~km}$ to the south, Morangan $6 \mathrm{~km}$ to the east. Other preserved temples in the neighbourhood include Gebang ( $7 \mathrm{~km}$ to the south), Kadisoka and Sambisari (respectively $8 \mathrm{~km}$ and $8.8 \mathrm{~km}$ to the south-southeast) as well as Kedulan ( $8.5 \mathrm{~km}$ to the southeast).

10. For a description and some pictures, see Hoepermans 1913: 255-256, OD photo nos. 1123711257, Edi Sedyawati et al. 2013: 130-131.

11. The site was first reported in 1923 and excavated in 1925 (Perquin \& Bosch 1925). Remains of three stüpas were discovered and transferred to Yogyakarta. Recently, three additional structures have been unearthed. One is clearly a stüpa. The nature of the other two structures is still unclear. 12. Namely Cepet, Karanggeneng, Ngepos, Suruh, Maron, Brengosan, Mriyunan, Jetis Jogopaten, Gondangan and Candikarang. Ngepos, Suruh and Maron are a few hundred metres away from each other and possibly form one site.

13. Cepet, Ngepos, Suruh, Brengosan, and Mriyunan. 
The amount and the variety of stones reported at Cepet, ${ }^{14}$ Ngepos-Suruh, ${ }^{15}$ Jetis Jogopaten ${ }^{16}$ and Candikarang ${ }^{17}$ suggest that ancient Hindu-Buddhist temples once stood in these four villages.

Candi Kimpulan is thus clearly not an isolated temple. It was part of a network of sanctuaries that covered the entire area between Borobudur and Prambanan and that was closely linked to wet-rice cultivation. ${ }^{18}$ Candi Kimpulan, however, was most probably located on the edge of this highly populated area and not in the middle of it, as few remains have been found north of Kimpulan. The upper slope of Mt Merapi was probably not as densely inhabited as the plain. Ground water availability and soil quality decrease as land rises, rendering higher grounds less suited to sustaining large population. On the basis of current knowledge, Candi Kimpulan might have been the main place of worship for villagers living within a $16 \mathrm{~km}^{2}$ area $^{19}$ - but this figure is probably slightly overestimated, since other religious sites might still lay buried under metres of volcanic debris..$^{20}$

14. Two dozens of roughly hewn temple stones are visible in the graveyard of the hamlet of Cepet (Purwobinangun, Pakem, Sleman), together with a yoni adorned with a $n \bar{a} g a$ surmounted by a turtle (it has been given the inventory no. B542 by the BPCB). A few stones are adorned with antefixes, but most of the ornamentation is unfinished. A second - unfinished - yoni with nagga is kept in the backyard of a nearby house. Former BPCB reports also mention the presence of a pinnacle, several antefixes, a small linga (B525), a peripih stone casket (B532) and two lids for peripih boxes (one round B533, and the other square [B534]) (Hasil pengumpulan Pakem). The amount and variety of stones suggest that a Hindu temple once stood in Cepet.

15. In the bathing place of the village of Ngepos (Ngepos, Donoharjo, Ngaglik, Sleman), one can see several ancient statues: a Gaṇeśa, a Viṣnu and an unidentified seated figure, as well as two bulls and a corner stone with antefix. According to Dutch reports, several carved temple stones were found in the area, together with a linga, a Durgā and a Gaṇeśa (Hoepermans 1913: 221; Bosch 1915: 18). A BPCB report states that not one but two statues of Ganeśa were still visible in the hamlet in 1977 (Daftar Peninggalan Benda DIY 1985: 96, 98, 103).

Suruh is located almost directly on the other side of the road. In the graveyard of this hamlet, are found a statue and as two dozens of temple stones, some of them carved with garlands of round lotuses. The statue is only roughly hewn and has been left unfinished. It is a standing male figure with a high headdress, holding a large bulging object - possibly a kendi - in his left hand. This latter detail, and the fact that the statue seems to have only two hands, suggests that it might be a representation of Agastya. Carved stones and a kāla were also reported in the nearby hamlet of Maron in the 19th century (Verbeek 1891: 163).

16. Numerous temple stones were noted here during the 19th century (Verbeek 1891: 163). Today, only two blocks are still lying in the kali Doso. In a nearby modern bathing place, two kālas and a stone slab adorned with a wishing tree flanked by kinnaris and birds are used as wall decorations (B265a, B266). Both kālas have paws and a lower jaw, which suggests a relatively late date (2nd half of the 9th century or later). The relief with kinnarīs is very similar to reliefs from Candi Prambanan, including in the style and composition of the jewel band that runs at the top and at the bottom of the slab.

17. Formerly, traces of a temple were visible here (Hoepermans 1913: 220), although Bosch was already unable to find it (Bosch 1915: 19). Several temple stones are still visible in the nearby hamlets of Candikarang and Candimendiro, possibly all coming from the place visited by Hoepermans in the 19th century. On the roadside, in the hamlet of Candikarang (Sardonoharjo, Sleman), one can see the lower part of a statue (B87) representing a male figure, sitting cross-legged on a padmāsana. Nearby lies a corner antefix and, in front of the mosque, the upper part of a kāla as well as a makara from a door frame, a couple of accolade-shaped antefixes, garland fragments and a few other carved stones. 18. Concerning the relationship between temples and irrigated rice cultivation in Central Java, see Degroot 2009: 95-100.

19. This figure is an estimate made by drawing Thiessen polygons around known neighbouring sites.

20. Until now, no site has been identified upstream of Kimpulan, along the Kladuan river. On the banks of the Gendol and the Dengkong rivers, however, Hindu-Buddhist sites are found up 


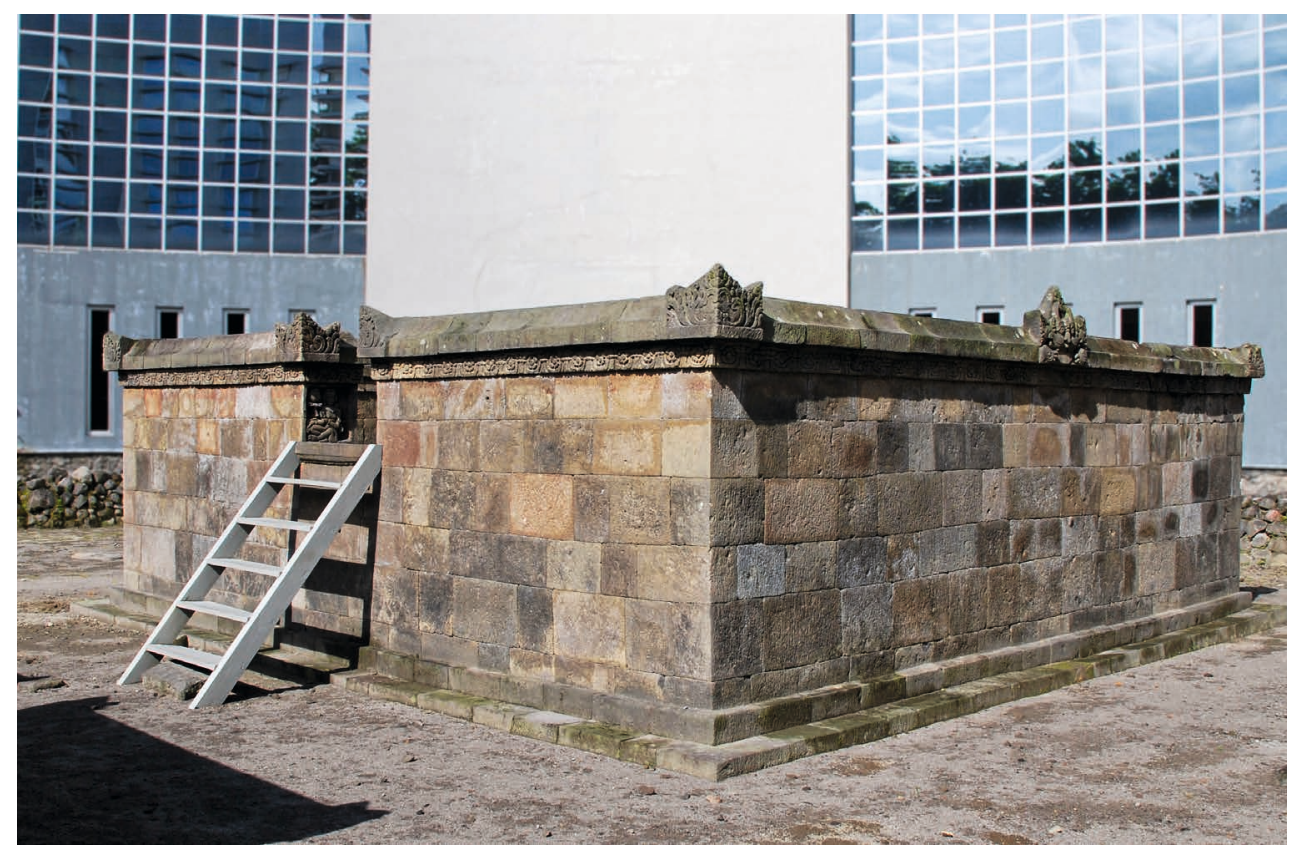

Fig. 3 - Candi Kimpulan. Main temple. General view of the façade (photo: V. Degroot/EFEO).

\section{Architecture and sculpture}

\section{Main temple}

Candi Kimpulan is not a very large structure. As one may infer also from its off-centre position, it looks more like a village or hermitage shrine than like a royal sanctuary. The main temple (fig. 3) measures $6.20 \times 6.20 \mathrm{~m}$ and faces northeast. ${ }^{21}$ Its foundation is composed of a single layer of roughly hewn stones, reinforced at the corners with river stones. Resting on this foundation, the first course of finely cut stones is partly buried and constitutes the base of the temple wall. This wall, underlined at the foot by a small plinth, has a total height of $2 \mathrm{~m}$. It ends with a frieze and a cyma and is adorned with antefixes. The entrance is a simple gap left at the centre of the eastern wall, with no traces of a door or staircase. ${ }^{22}$

The wall of Kimpulan's main building is constituted of ten courses of stones of varying heights. Most blocks are rectangular, but some are cut at an angle so as to reinforce the cohesion between courses (fig. 4). A few stones function as locking wedges. Damage suffered by the northwestern and southeastern corners has revealed that the wall - except for the uppermost course - is two stones thick (fig. 5). The narrow space between the blocks

to an altitude of $500 \mathrm{~m}$ and $570 \mathrm{~m}$ respectively. It is thus very likely that the same applies for the area along the Kladuan.

21. There is a deviation of $19^{\circ} 18^{\prime} 56^{\prime \prime}$ from due east.

22. A stone was discovered on the ancient ground level, $40 \mathrm{~cm}$ to the east of the entrance. It probably served as stepping stone for a wooden staircase, as it does today. 


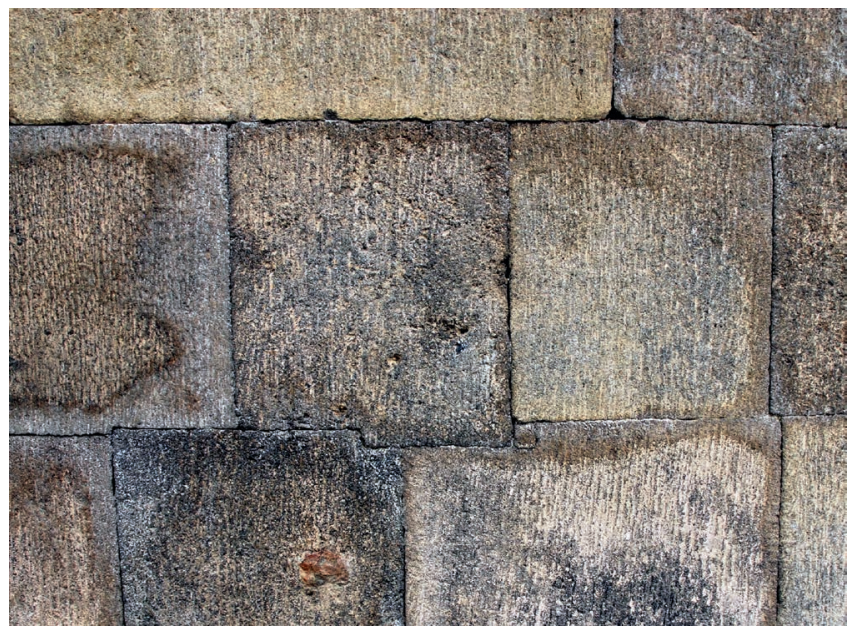

Fig. 4 - Candi Kimpulan. Main temple. Detail of the stereotomy (photo: V. Degroot/EFEO).

Fig. 5 - Candi Kimpulan. Main temple. Detail of the northwestern corner during excavations (photo: BPCB DIY).

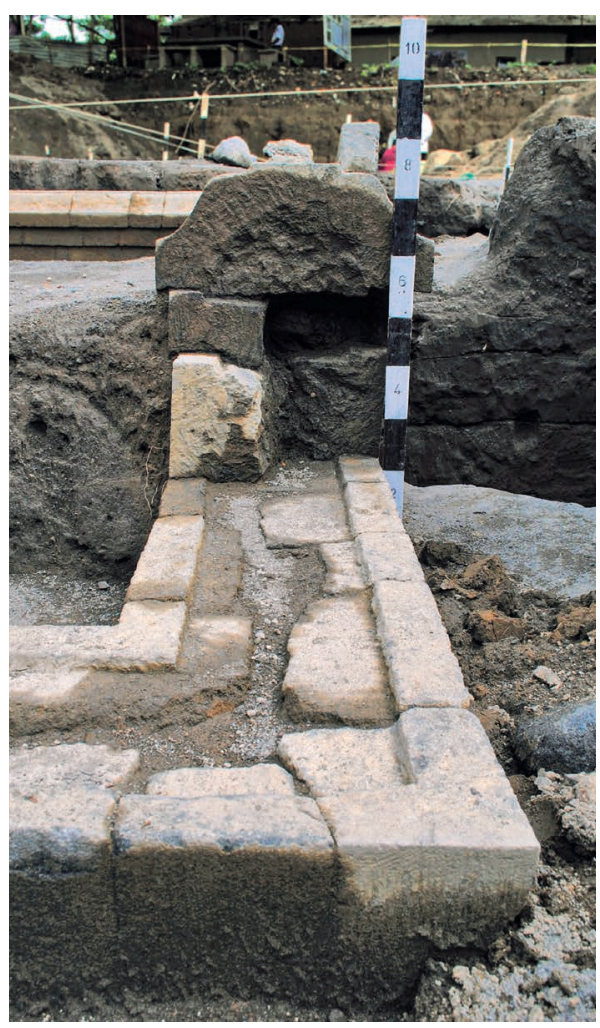

is filled with clay. The lower face of each stone is cut so as to slide within the course beneath it. As is often seen in Java, the temple is not entirely built in stone. Its wall actually functions as a retainer to create a sort of stone box filled with $1 \mathrm{~m}$ of packed earth and covered by a stone pavement. The latter is made of a single layer of stones of varying sizes and shapes, often cut at angles, but generally less well adjusted than the stones of the wall. ${ }^{23}$ Roughly at the centre of the terrace, slightly protruding paving slabs form a square of ca. $1 \times 1 \mathrm{~m}$ on which rests a linga-yoni (fig. 6).

On the terrace, at the surface of the pavement, one can see 23 circular stones, divided into two series (fig. 7). The outer row is made of 12 large stones, i.e. 4 on each side. They are $35 \mathrm{~cm}$ in diameter. These circular stones are actually the top part of bulge cylinders buried below the pavement. Their upper face crops out very lightly at the surface of terrace and pavement stones have been cut to match their shape. The cylindrical stones were evidently placed before the pavement was laid. Stratigraphy has shown that these stones were pillar bases: traces of (former) posts have clearly been identified on top of them during excavations. ${ }^{24}$

23. Their surface is also less smooth. Traces of pick-like tools suggest that the pavement stones had not received a surface treatment yet, by contrast with the blocks from the wall, which had been chiselled.

24. The posts were removed at some stage before the total burial of the temple, but the hole left was filled with a distinctive soil. See below, p. 83 fig. 8 and p. 108 . 


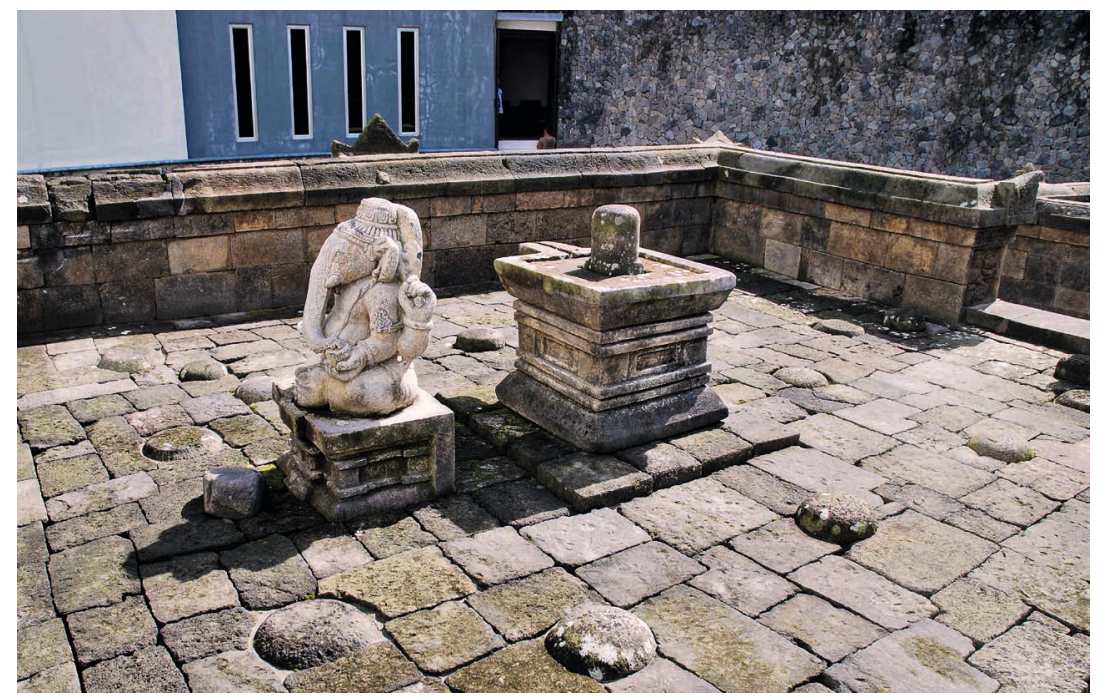

Fig. 6 - Candi Kimpulan. Main temple. General view of the inside, with linga-yoni, Ganeśa, pillar bases and round stones (photo: V. Degroot/EFEO).

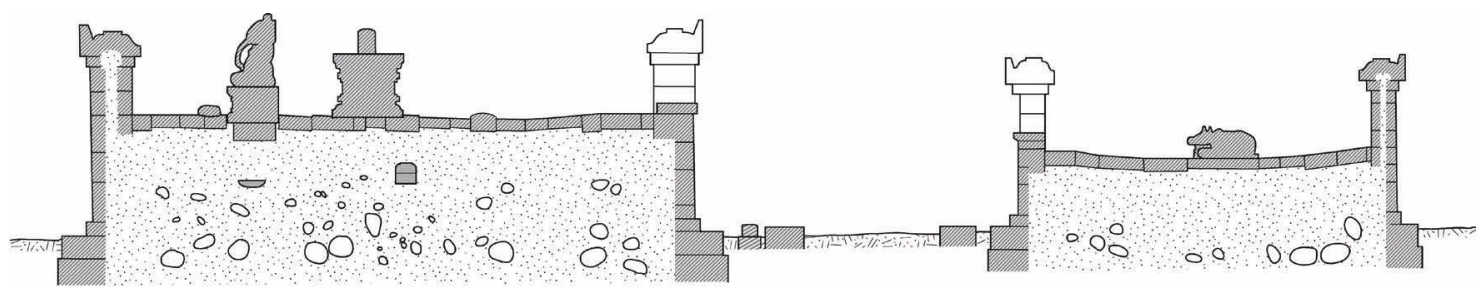

$A_{N}$
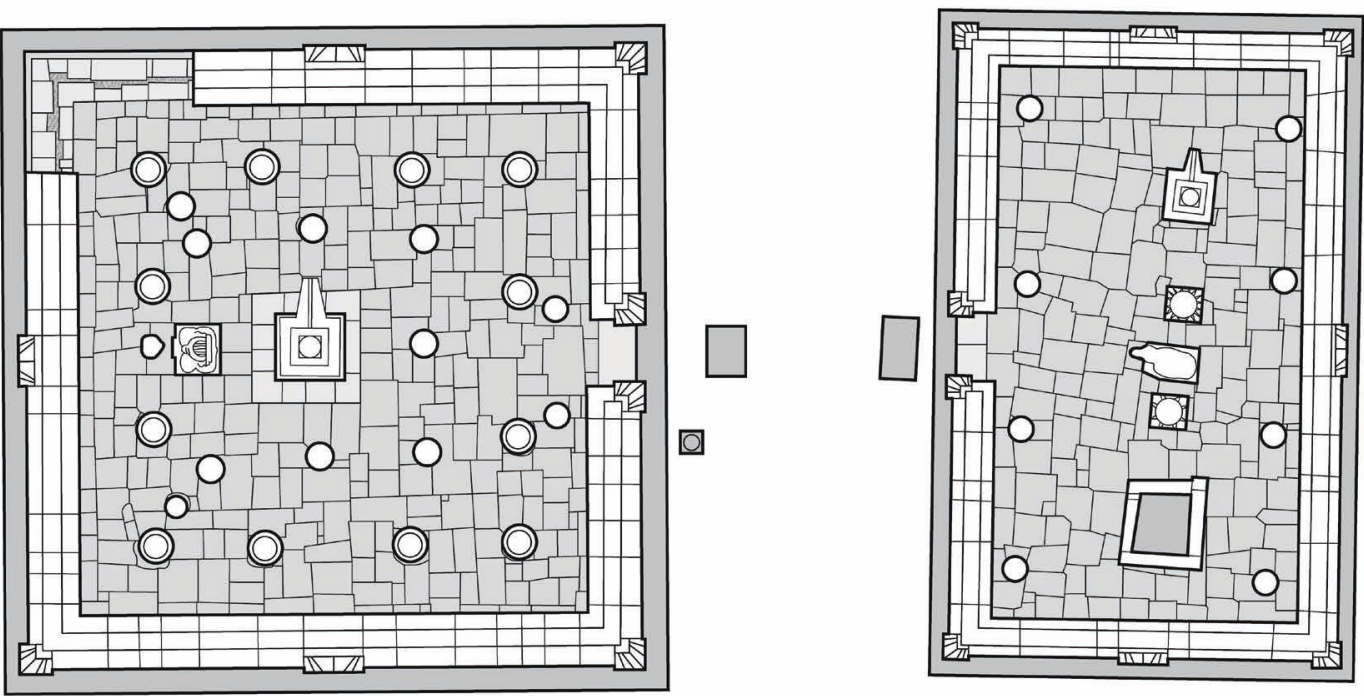

Fig. 7 - Candi Kimpulan, ground plan and cross-section of the temples (adapted from Gambar No. YEL02P06345, BPCB DIY, 2010). 
Circular stones of the second series are smaller ( $c a .20 \mathrm{~cm}$ in diameter) and have a cylindrical shape. Unlike the large ones, these small stones have a convex upper face that rises a few centimetres above the pavement. Their height corresponds roughly to the thickness of the paving stones (fig. 7). ${ }^{25}$ Their distribution is uneven. Seven of them form a sort of inner row around the yoni, while two of them flank the entrance and the last two stones are found in the northwestern and southwestern corners. The stones of the inner row are not in a line; nor are they in a line with the large stones of the outer row. This lack of consistency makes it very unlikely that both series of stones - the large ones and the small ones - were meant to support parts of the same structure. It has been proposed that the superstructure of Candi Kimpulan was similar to that of Javanese mosques: a double roof resting on a double row of pillars (Balai Pelestarian Peninggalan Purbakala Yogyakarta s.d.: 97, fig.). But we doubt that this was ever the case, not only because of the misalignment of the two series of pillars and the round surface of the small stones, but also because of the technical implications of this type of double roof. In a Javanese mosque - or in a joglo ${ }^{26}-$ the inner pillars support the upper roof and bear the heaviest weight. They are thus higher and thicker than the outer ones. At Candi Kimpulan, the small bases are inside, the large ones outside. Actually, the small round stones may have not been pillar bases at all. Not only is their convex surface not ideal for such a function but, by contrast with the large stones, where traces of posts were clearly visible in the stratigraphy, no such traces were noticed for the small ones (fig. 8). It is possible that the small stones had a ritual, rather than an architectural function, possibly as markers of the directions. ${ }^{27}$ That round stones placed on the temple terrace had sometimes a religious function as markers of the directions is attested at Candi Gunung Sari, a Hindu temple located in the district of Magelang and dating from the same period as Kimpulan. The cylindrical stones from Gunung Sari bear short inscriptions designating the four cardinal points and the interim directions (Degroot, Griffiths \& Baskoro Tjahjono 2010-2011). Another possibility is that the structure that these small circular stones supported was very light and left no visible trace - maybe some sort of canopy made of light wood or bamboo. ${ }^{28}$ But whatever the function of the inner set of stones - bases for a canopy or markers - Candi Kimpulan was most

25. Whereas most of them are placed in gaps within the pavement, the two small stones near the entrance rest on the pavement, in shallow cavities.

26. The joglo is the traditional house of Javanese aristocracy. It has a characteristic hip roof with a tall peak at its summit and is supported by four central pillars.

27. The large pillars are placed so to allow passage between them: there is no pillar in the axis of the entrance. The small stones of the inner row, however, are placed according to the points of the compass: in the east, southeast, south, southwest, northwest, north and northeast. There is no stone in the west because this place is occupied by a statue of Ganeśa.

28. We do not know of an existing example of canopy inside a Central Javanese temple. But these structures were well-known in Cambodia, where they were sometimes made of stone, such as in Sambor Prei Kuk. We thank our EFEO colleague, Bruno Bruguier, for underlining this possibility and suggesting that the stones doubling the stones of the northwest and southwest corners may have been traces of braces needed because of the absence of a central pillar on the west side of the canopy - the place being occupied by the Ganeśa statue. 


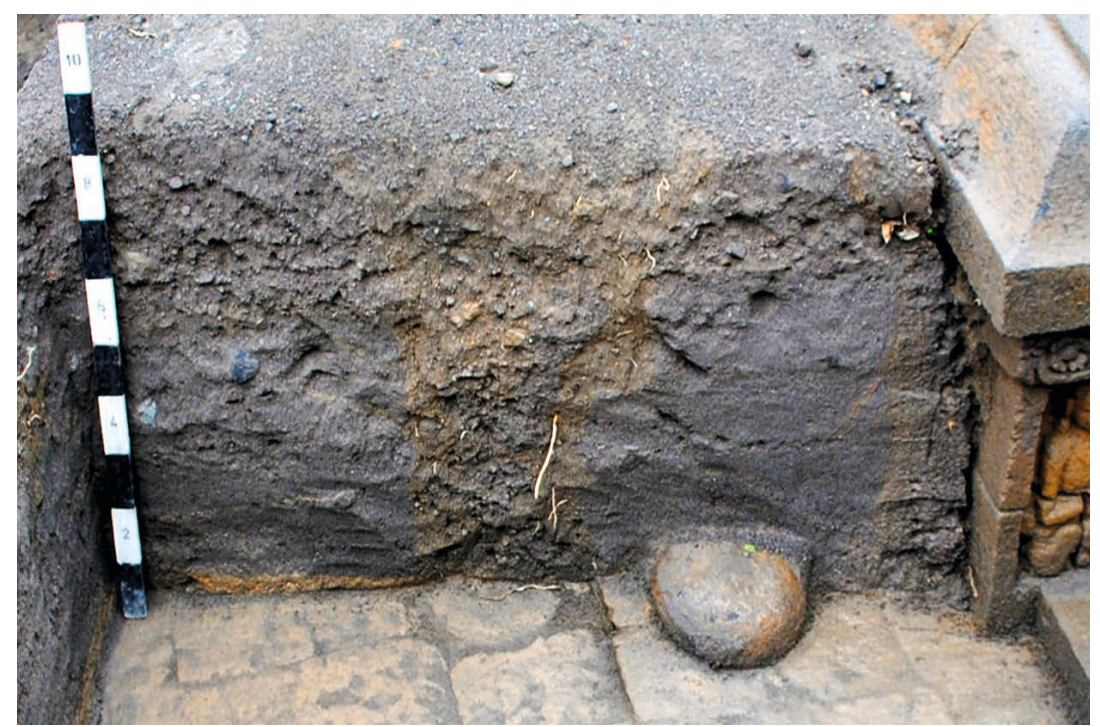

Fig. 8 - Candi Kimpulan. Main temple. Trace of a filled posthole above one of the large cylindrical stone. Note the absence of a similar feature above the other round stone (photo: BPCB DIY).

probably not covered with a double-tiered or a joglo-type roof, but with a single radiating wood frame. ${ }^{29}$

Candi Kimpulan has very little ornamentation. The only carved elements are a frieze, nine antefixes and two small decorative panels. The frieze runs around the outer face of the wall, right below the cyma (fig. 3). It is composed of the usual garland motif, embellished with lotus flowers (fig. 9). This motif is relatively frequent in Central Javanese architecture, although the Kimpulan version is simpler and squarer than most other known examples. ${ }^{30}$ The frieze was underlined by a band of red paint $8 \mathrm{~cm}$ thick, traces of which are still clearly visible on the wall surface. ${ }^{31}$

Antefixes adorning Kimpulan's main temple are of three different types (figs. 3 and 10). At the corners and on each side of the entrance, one finds

29. For a note about this type of roof and its use in ancient Java, see Dumarçay 1973; 1986: 26-29. The example of Candi Kimpulan shows the difficulty of reconstructing the elevation of wooden buildings on the sole basis of their ground plan. Each case requires close scrutiny. Not all "pillar bases" are likely to have served such a function. Besides, one should keep in mind that concentric series of pillars do not necessarily equate with multiple roofs - and the other way round. Wide buildings covered with hip roofs may require additional supports and leave on the ground the same traces as double roof structures - imagine, for example, what would be left of the Embekke Devalaya temple of Kandy if only pillar bases remained. Conversely, the multiple roofs of Balinese merus are not always visible on their ground plan. For a drawing of the timber structure of Balinese meru, see Dumarçay 1993: 142, pl. VIII.

30. Compare, for example, with Sambisari and Kedulan. Flat and squarish garlands are also found on the stones allegedly from Candi Perot and now gathered together in front of Candi Pringapus. But most of them figure birds rather than lotuses and the couple of stones figuring lotus garlands are strongly weathered.

31. This tends to prove that this temple was not covered with plaster as were, for example, Candi Borobudur and Kalasan. A paint with a similar tint has been used for an inscription on the balustrade of the Siva temple in Prambanan (Tjahjono Prasodjo 2013: 21, fig. 6). 


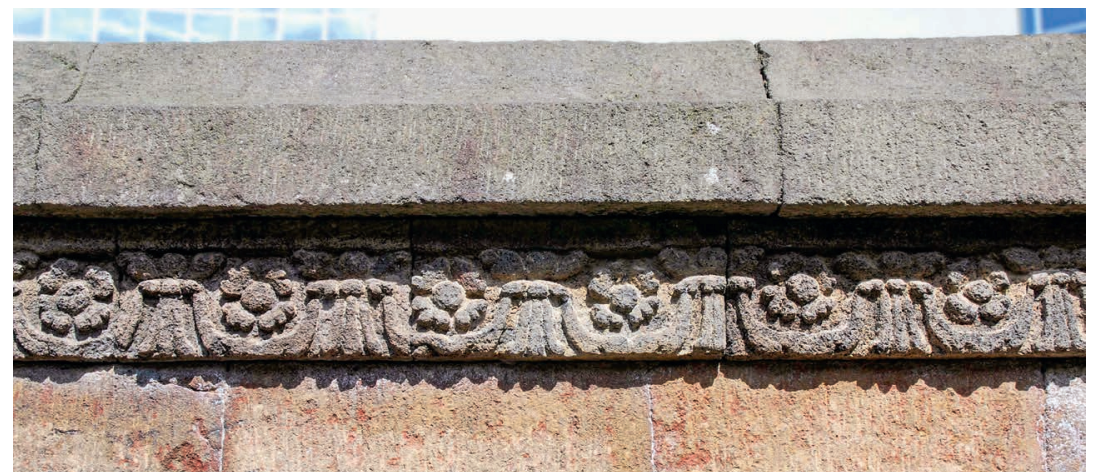

Fig. 9 - Candi Kimpulan. Main temple. Lotus frieze and traces of a band of red paint (photo: V. Degroot/EFEO).
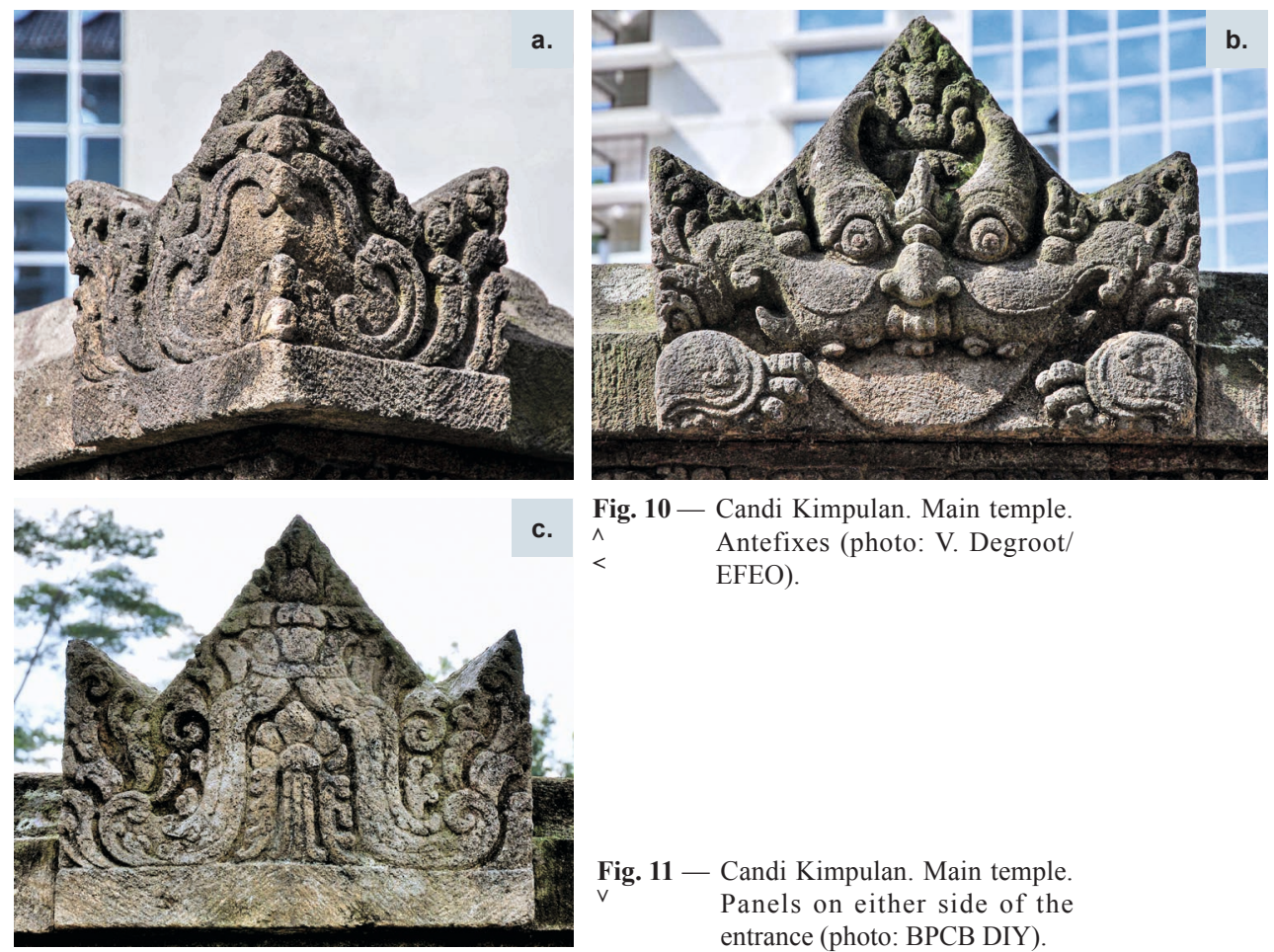

Fig. 10 - Candi Kimpulan. Main temple.

$\wedge \quad$ Antefixes (photo: V. Degroot/ EFEO).

Fig. 11 - Candi Kimpulan. Main temple. Panels on either side of the entrance (photo: BPCB DIY).
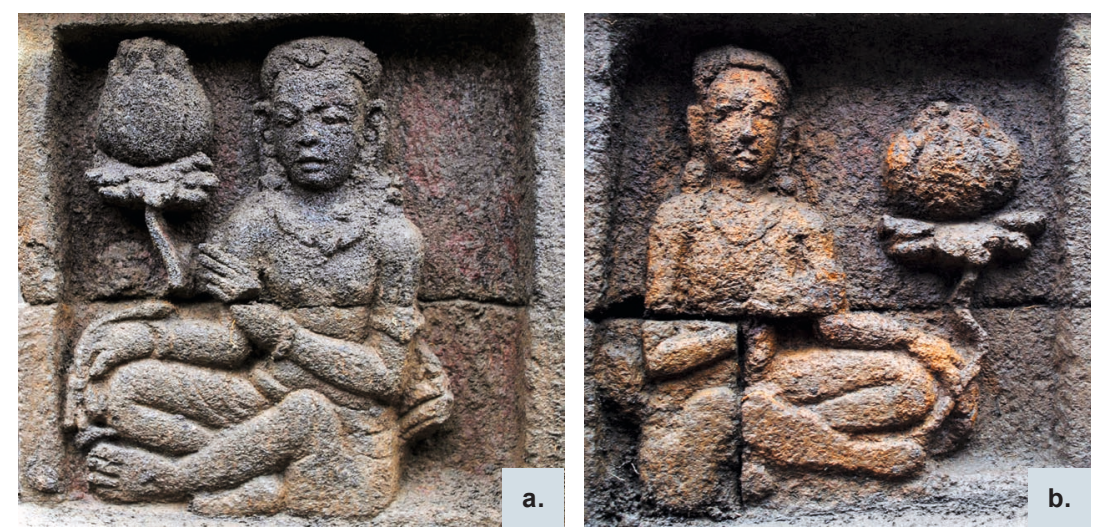
three-pointed corner antefixes carved with a bulb/jewel motif and plant decorations (fig. 10a). The motif in itself is quite common, but the way it is depicted at Candi Kimpulan finds particularly close matches in the antefixes from Sambisari ${ }^{32}$ and Sojiwan..$^{33}$ The centres of the western, southern and northern walls are marked by larger antefixes, bearing different motifs. On the western antefix, one can see a pointed arch, topped by a flower and surrounded by plants, sheltering an open lotus, a hanging string of beads and two leaves (fig. 10c). ${ }^{34}$ In this case as well, a very close match is found at Sambisari. ${ }^{35}$ The southern and northern antefixes bear yet another motif: it is a kāla head sticking out its tongue (fig. 10b). The absence of a lower jaw could indicate an early dating, but the presence of paws and detached horns tell otherwise and suggest a terminus post quem of $c a .830 \mathrm{CE} .{ }^{36}$ The shape of the different antefixes seems to point to the same date, since they have been identified as characteristic of the Ijo-Plaosan style (Degroot \& Klokke 2010).

The last element of decoration of Kimpulan's main temple are two small reliefs carved in the thickness of the wall, on either side of the entrance (figs. 3 and 11). They both depict the same motif: a male figure sitting crosslegged and looking outwards, ${ }^{37}$ one hand raised at chest level and the other hand resting on the knee, holding the stem of a lotus. The figures wear a short loin cloth and are adorned with jewels - heavy ear pendants, necklace and bracelets. We have not been able to identify these representations. We only know of one other Central Javanese temple with comparable figures in a similar place: Candi Pringapus, in the district of Temanggung. ${ }^{38}$

The inner space of Candi Kimpulan is plain and free of ornamentation. At the centre of the terrace stands a linga-yoni and, in the west, a statue of Ganeśa (fig. 6). ${ }^{39}$ The yoni is plain and of the usual type. It measures $66 \times 66 \times 58 \mathrm{~cm}$. A linga of $18 \times 18 \times 38 \mathrm{~cm}$ fits in it. The upper half of

32. More specifically the corner antefixes and the small subsidiary antefixes of the roof top of the main temple.

33. See photo OD 11662.

34. This antefix differentiates the western side from the north-south axis and emphasises the sacredness of the rear, the place where Ganeśa sits.

35. This motif is similar to the one found on the central antefixes of the first storey of Sambisari's superstructure.

36. The paws seem to appear with the Plaosan style. But in Plaosan, as in most (all?) other examples from Central Java, kālas with paws always have a lower jaw. The emergence of the detached horns is more difficult to date. There is one example on a loose lintel found in Sojiwan, and a few occurrences at Loro Jonggrang (mid-9th century). The kāla on the Kimpulan antefix actually bears some similarities with kālas from Candi Barong, Pringapus and Perot.

37. The figure on the right side of the door (upon entering the temple) is outlined but the details are not fully carved.

38. At Pringapus, the lotus bearers are also depicted sitting cross-legged on both side of the entrance, but they are carved on the outside walls of the porch. The lotus stem that they hold in their hands transforms itself into an ornamental scroll. See OD photograph no. 11416.

39. The linga-yoni is actually not at the exact geometrical centre of the terrace: it is off by $25 \mathrm{~cm}$ to the northwest. This was most certainly done on purpose, although a displacement to the northeast might have seemed more appropriate. The Mayamata (33.37b-38a), for example, says that "the wise man must place the linga or the image at the centre of the cella, but to the left of the line (that passes through its exact centre) and with a slight shift to the northeast" (Dagens 1976: 282). The Rauravāgama (28.68) prescribes the same thing (Barazer-Billoret 1993-1994: 58, n. 53). 


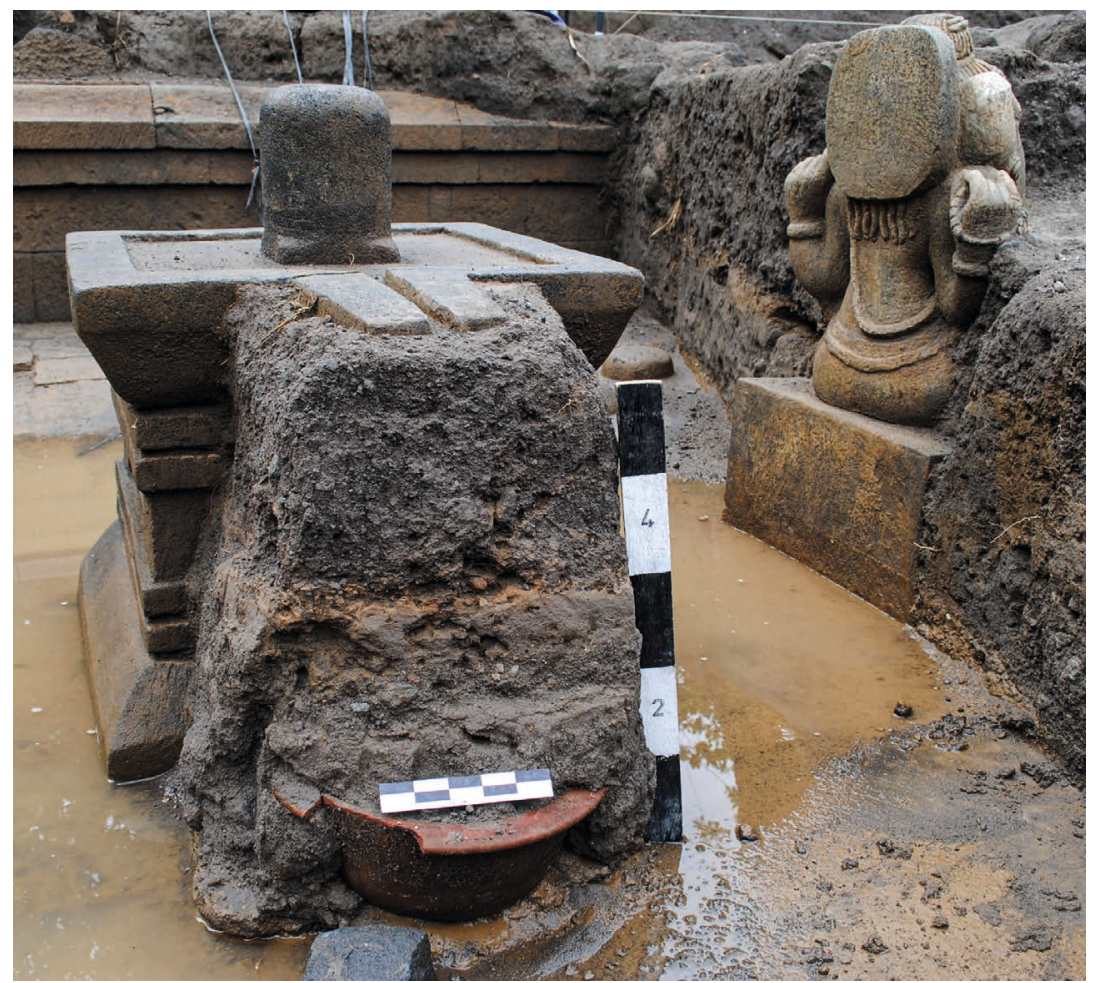

Fig. 12 - Candi Kimpulan. Main temple. Large earthenware near the yoni pedestal during excavations (photo: BPCB DIY).

the linga is cylindrical, the lower half has a square section. ${ }^{40} \mathrm{~A}$ thin double line, drawing a kind of loop, has been carved on the round part. ${ }^{41}$ During excavations, a large earthen pot was discovered below the drip line of the ablution channel (fig. 12). ${ }^{42}$ The presence of this pot shows that, even in the

40. Whereas lingas are supposed to count three parts - circular, octagonal and square - representing respectively Śiva, Viṣnu and Brahmā, the linga of Candi Kimpulan has only two sections (round and square). It is possible that the primary reason was a practical one: the yoni pedestal is rather small. If a cavity deep enough to fit a three-part linga had been carved, the pedestal would almost be bored-through. However, the result - a two-part ling $a$ - was judged acceptable by local religious authorities, establishing the primacy of Siva and the ancillary character of Viṣnu and Brahmā. Two-part lingas are actually not totally unheard of. There are several Khmer examples from the pre-Angkorian period (Goodall 2017, figs. 4 and 5) and they are alluded to in an early Mantramārga text, namely the Sarvajñānottara (19.53) (Goodall 2017: 63-66). The Kimpulan linga, however, with its flattened head and stylised traits is certainly of a later period.

The linga of Kimpulan raises another matter. Javanese archaeologists - ourselves included have often distinguished between "real" linga (main focus of worship) and linga-shaped stone markers on the basis of their composition (two or three parts). The presence of a two-part linga within the yoni pedestal of Kimpulan proves our criterion to be wrong and gives reason for a reevaluation of previous identifications.

41. These lines, which are supposed to represent the corona and the meatus of a phallus, have been transformed into stylised markings. About the sexual aspect of the linga, see Brunner 1993. The linga of Candi Kimpulan was discovered in place and untouched. It was turned so that the loop/meatus was visible when entering the temple, as it is still the case in Indian temples today. 42. The pot has a maximum diameter of $33 \mathrm{~cm}$ and a height of $16 \mathrm{~cm}$. It is covered in red slip inside and outside. It shows horizontal traces of smoothening as well as traces of burnishing. 
absence of a somasūtra, liquids used to anoint the linga were not spilled on the ground but were collected and, possibly, distributed to worshippers. ${ }^{43}$

To the west of the linga-yoni stands a statue of Ganeśa that measures $67 \mathrm{~cm}$ in height (fig. 13). The god faces west and is depicted in his usual posture: fourhanded, seated with the soles of his feet touching one another. In his right hands, he holds a rosary and his broken tusk. In his left hands, he holds a small axe and a bowl. His long hair is gathered in an ascetic's knot and adorned with a string of beads. ${ }^{44} \mathrm{He}$ is wearing bracelets and a $n \bar{a} g a$ as sacred thread. The sculpture is simple but of high quality and was carved with masterly technique. ${ }^{45}$ No trace of any other statue was found and it can safely be concluded that Candi Kimpulan was not built to house the traditional Javanese triad - Agastya, Durgā, Gaṇeśa. The main deities obviously were Śiva and the elephant god. ${ }^{46}$ Ganeśa does not sit on a lotus cushion, as would befit a god of his rank, but rests directly on a pedestal. The lower part of

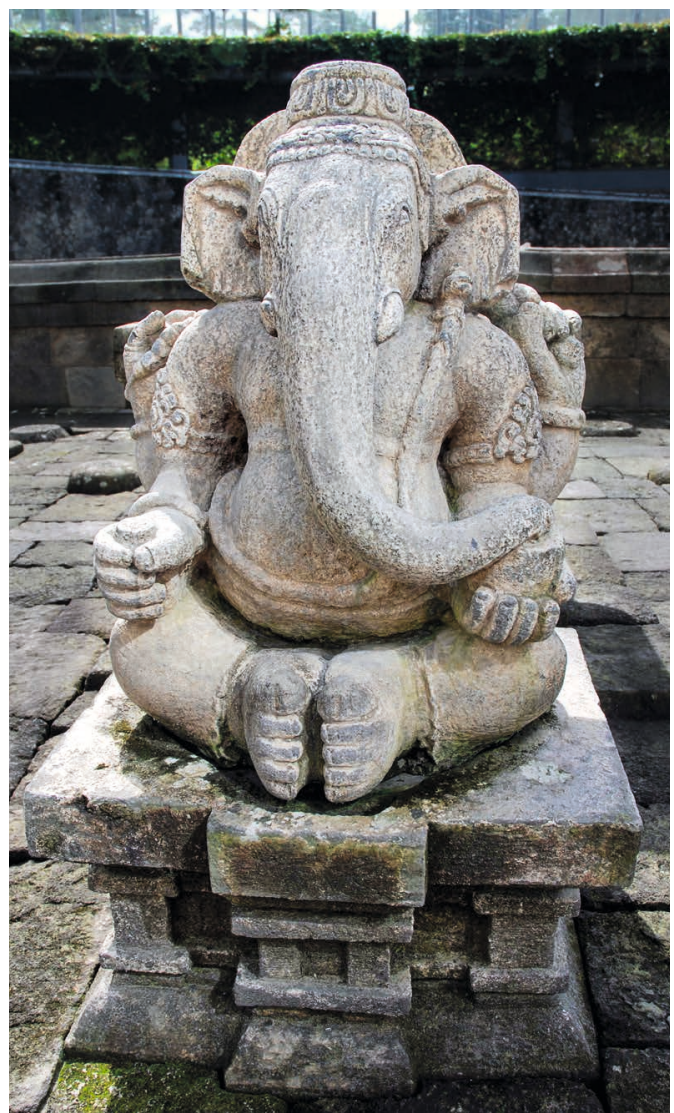

Fig. 13 - Candi Kimpulan. Main temple. Statue of Gaṇeśa (photo: V. Degroot/EFEO). the pedestal is hidden by the pavement, which suggests that the pavement is a late addition and that the terrace initially had a dirt floor. ${ }^{47} \mathrm{~A}$ small irregular stone was placed in front of the statue, probably as place for laying offerings to the deity. ${ }^{48}$

43. In the Hindu architecture of Java, somasūtras are exceptional. We know of only two such devices, one at Candi Arjuna (Dieng), the other at Candi Singosari (East Java, late 13th century). At Candi Merak, a bronze pipe going through the pavement and linking the yoni to the peripih was discovered (Perquin 1927). A similar pipe system has recently been discovered in one of the two small temples of Gedong Songo IV. There was no such thing at Candi Kimpulan.

44. He does not wear the skull and the moon in his headdress. Although most Central Javanese Gaṇeśas wear these symbols, there are a few notable exceptions, such as the beautiful Ganeśa from Candi Banon, now kept at the National Museum in Jakarta (Inv. no. 186b/4845). For a picture of the latter statue, see Nelson et al. 2005: 20 and OD pictures 1169a, 1172a.

45. Contrary to most Central Javanese sculptures, the Ganeśa of Kimpulan is carved in the round: it does not sit against a stele and details of its back are carved as well.

46. About the importance of Ganeśa in Central Java, see below, p. 101.

47. This could explain the difference between the finely cut stones used for the wall and rough blocks used for the pavement. The pedestal of Ganeśa rests on another large stone - roughly hewn that served as a foundation and was meant to prevent it from sinking.

48. Another stone - rectangular in shape - crops out at the surface of the pavement, west of the northeastern pillar base. Its function is unknown but its position in the northeast is striking, this direction being especially sacred in Bali. 


\section{Subsidiary shrine}

Kimpulan's subsidiary shrine faces the main temple (figs. 1 and 7). It measures $3.5 \times 6 \mathrm{~m}$. The construction technique is similar to that of the main temple, but the structure is lower: it has only 7 stone courses in elevation $(1.85 \mathrm{~m})$ and the pavement is $85 \mathrm{~cm}$ above ancient ground level. At the surface of the terrace, one can see eight flat circular stones measuring $25 \mathrm{~cm}$ in diameter. These are the upper faces of stone cylinders anchored in the dirt filling of the temple. The paving stones of the terrace have been cut so as to fit their round shape. Traces of posts have been identified atop most of these cylinders, so that it is safe to call them pillar bases.

The ornamentation of the shrine was left unfinished: antefixes were placed but never carved. Small antefixes adorn the corners and both sides of the entrance, while larger ones are placed at the centre of the façades. The convex shape and the sharp axial edge of the northern and southern antefixes indicate that they were meant to be kâlas, just like those of the main shrine (fig. 14). The eastern antefix is flat and was probably supposed to bear a different motif - possibly plant-like.

The terrace is not empty. Roughly on a north-south line, stand a lingayoni (north), a bull flanked with two small pedestals (centre), and a pit (south). The lower part of the yoni and of the altars - and possibly also of the pit - is hidden by paving stones (figs. 15 and 16), which suggests that the pavement was added afterwards, probably to replace a dirt floor. The linga-yoni resembles the one in the main shrine, albeit smaller. ${ }^{49}$ The two small pedestals are similar in shape and dimensions: ${ }^{50}$ they are small cubic stones with a simple moulding, surmounted by lotus petals and topped by a circular plate. The lotuses, however, are depicted differently. The lotus of the northern pedestal is composed of a single row of 16 petals. The flower of the southern pedestal is made of two rows of eight petals, the outer ones being considerably larger than the inner ones. This difference in ornamentation possibly indicates that the altars were meant for different divinities. ${ }^{51}$ These pedestals may be what are referred to in India as balipithas, i.e. altars to leave food offerings. In India, such offering tables are attested in the archaeological record as early as the 5th century (Willis 2009: 103). ${ }^{52}$ Although they have become more and more complex over the centuries, balipit thas are invariably composed of a square base, a lotus and a round

49. The yoni measures $55 \times 55 \times 56 \mathrm{~cm}$, the linga has a diameter of $13 \mathrm{~cm}$.

50. The northern pedestal is $36 \times 35 \times 43 \mathrm{~cm}$, the southern one $37 \times 36 \times 45 \mathrm{~cm}$.

51. Small pedestals of this type, but adorned with four naggas are visible at Candi Ijo, where they were also found in situ, and at Sambisari and Kedulan. But they most probably used to be part of the usual temple paraphernalia. Similar pedestals have for example been found among loose stones at Medono (Batang), Nyatnyono, Tegalsari and Gedong Songo (Semarang), as well as at Gondosuli (Temanggung).

52. According to Willis (2009: 103), the oldest surviving balipitha in north India was found in Rāmgarh, a Gupta site in Central India. A simpler form of balipițha is to be seen in the cave 2 in Badami: it is a simple lotus carved directly in the ground (Willis 2009: 103-104; Burgess 1874: plate XXII; Digital South Asia Library [https://dsal.uchicago.edu/index.html]: accession no. 54780). 
Fig. 14 - Candi Kimpulan. Secondary temple. Unfinished antefix (photo: V. Degroot/ EFEO).

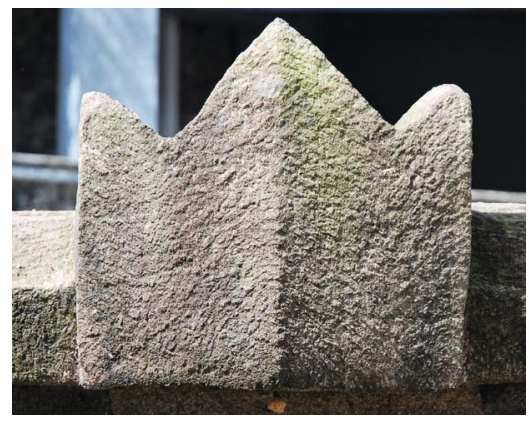

Fig. 15 - Candi Kimpulan. Secondary temple. Internal space, viewed from the south. Altars, bull and linga-yoni (photo: V. Degroot/EFEO).

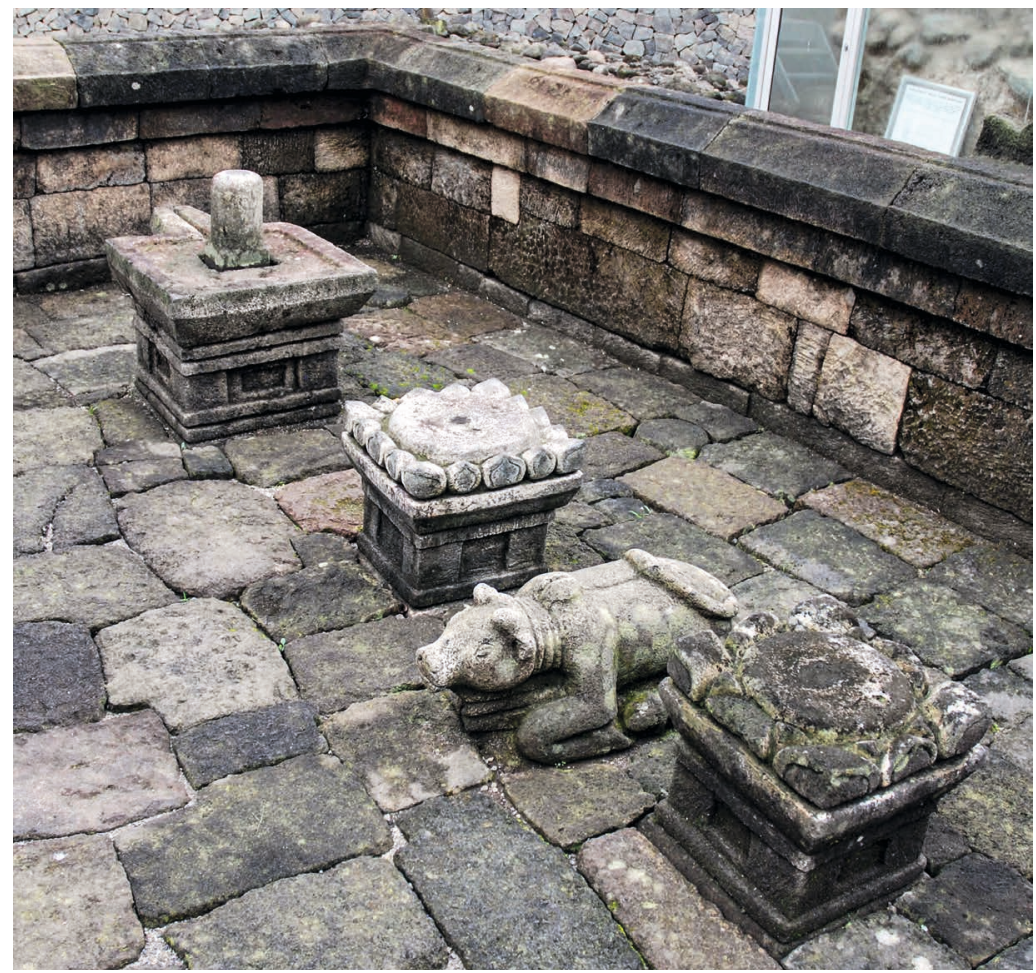

Fig. 16 - Candi Kimpulan. Secondary temple. Linga-yoni and altar (photo: V. Degroot/EFEO).

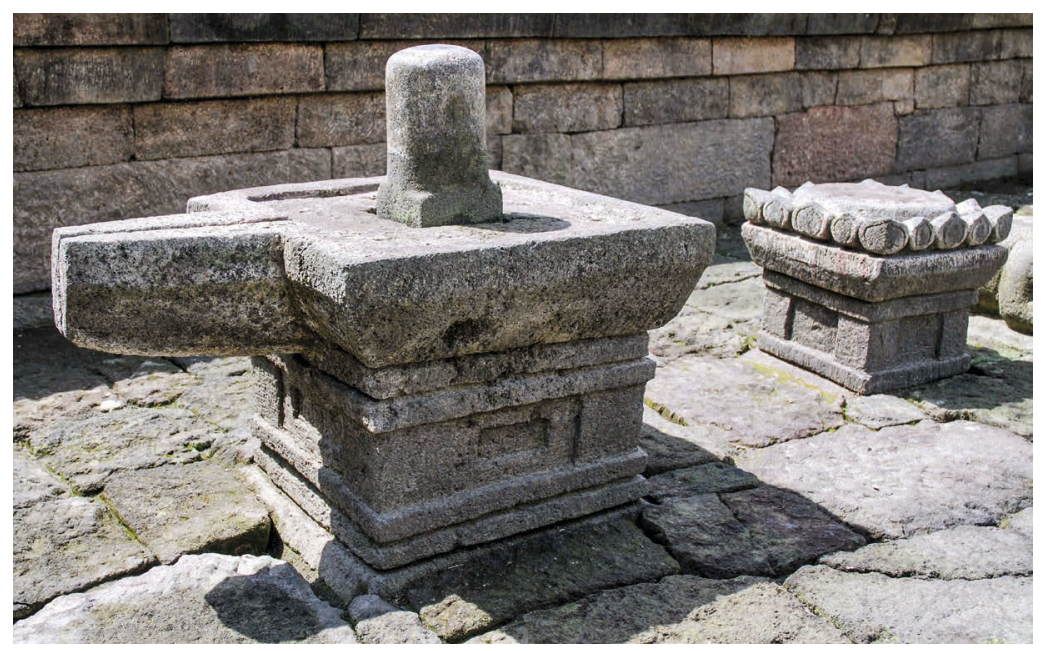


table. ${ }^{53}$ The earliest known mention of the word balipit tha is to be found in a south Indian inscription from Nārttāmalai, near Pudukkottai (Francis 2015, personal communication). From the 12th century onwards, balipithas are also mentioned in Indian Śaiva literature (Goodall, forthcoming) ${ }^{54}$ There is no agreement as for the ideal number and position of balipit thas within a temple complex, but in the texts as well as in the Indian architectural tradition, there is a tendency to place at least one balipit tha near the main gate (either within or without the courtyard). In some 9th-century south Indian temples, ${ }^{55}$ the balipit tha is placed next to Siva's bull - as it is the case in Candi Kimpulan. The proximity between the balipitha and the bull is also described in the 12th-century Jñannaratnāvalī: "The balipițha, the bull, [and] the trident should be placed facing that face" (Goodall, forthcoming). However, we have been unable to find any textual mention or architectural example of a bull flanked by two balipit thas. ${ }^{56}$

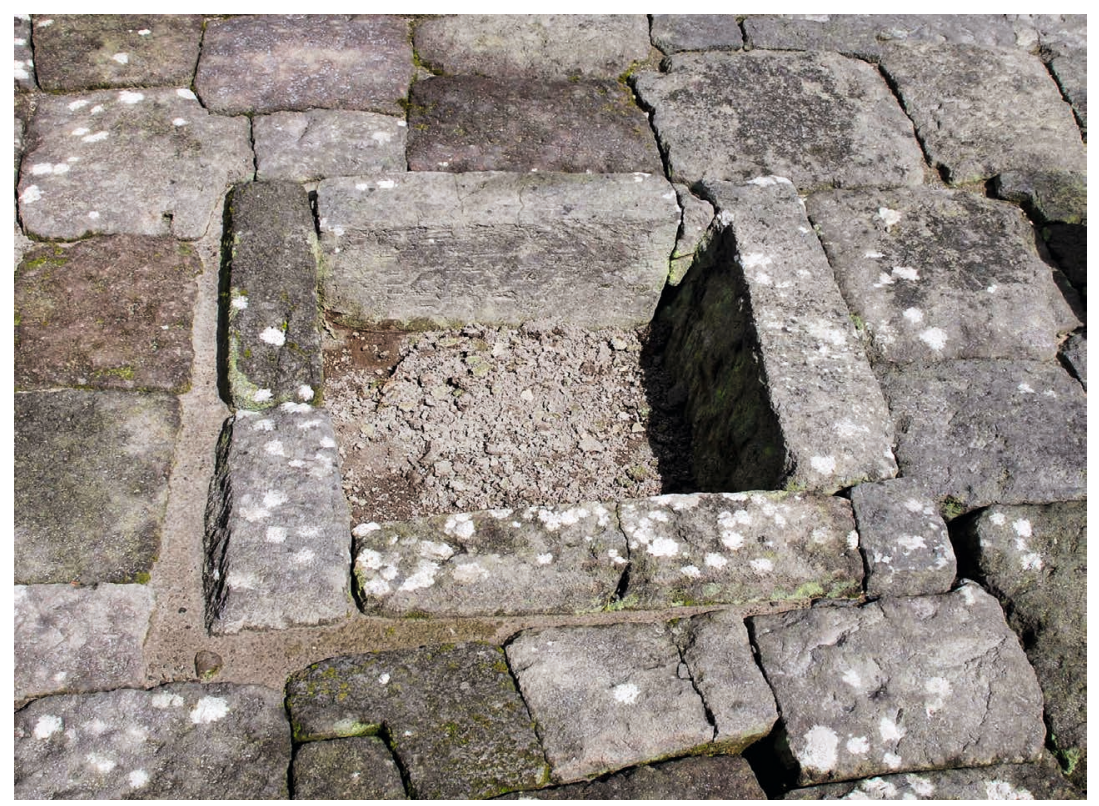

Fig. 17 - Candi Kimpulan. Secondary temple. Fire altar (?) (photo: V. Degroot/EFEO).

Right to the south of Siva's bull and the altars, one can see a shallow pit, bordered by long stones slightly cropping out at the surface of the pavement (fig. 17). The pit measures ca. $80 \times 80 \mathrm{~cm}$ (outside), $52 \times 52 \mathrm{~cm}$ (inside), and is about $50 \mathrm{~cm}$ deep. Its bottom is made of flat river stones. The function of this

53. Balipịthas are also known in Cām art, where they have sometimes taken dramatic proportions and developed a complex iconography. It is the case, for instance, of the Van Trac Hoa pedestal (ca. 9th century CE). See Baptiste 2003.

54. We have not found references to balipițhas in Central Javanese inscriptions.

55. For example, at the Tirukkattalai Sundaresvara temple near Pudukkottai.

56. We do not know whether this configuration was usual in Java either. At Candi Ijo, the only other temple where a bull and a balipit tha were found in situ, there is only one altar, placed to the right of the bull. 
pit is not known but it is strongly reminiscent of fire altars that are still built for some rituals in India today. Several inscriptions from the Central Javanese period show that offerings to saì hyai Brahmā were an integral part of sima demarcation ceremonies, and, as noted by Titi Surti Nastiti et al. (1982: 46, n. 74), the term refers to the sacred fire rather than to the Hindu god. This identification is made clear by a passage from the Panggumulan I inscription (902 CE), which reads saì hyan் Brahmā tumunū ikan் kayu, i.e. "sañ hyan் Brahmā sets the wood alight" (III.a.16). The Gilikan I inscription, dated 923 CE, confirms the use of a square sacrificial fire pit (san hyan Brahma caturasra kunda) by the priest in charge of the ceremony. Besides, there are repeated allusions to burnt offerings and firewood for sacrifices in the Old-Javanese Rāmāyaṇa, the principal surviving literary text from the Central Javanese period. In stanza 1.24ff., for example, one finds the description of a sacrifice held by king Daśaratha to obtain children, during which Śiva manifests himself in a "fiery hearth" (kunda bahnimaya) (Robson 2015: 37ff.; van der Molen 2015: 6ff.). ${ }^{57}$

The fact that Candi Kimpulan has been extremely well preserved and that the subsidiary temple was found intact with all elements still in situ, casts interesting light on the debate of the function of the secondary shrines, called candi perwara in Indonesian archaeology. Many Hindu sanctuaries of Central Java are composed of a main temple facing one or three such subsidiary shrines (Degroot 2009). Since most of them have been found empty, the function of these small buildings has remained elusive. Until now, the only solidly established fact was that, if any statue was found in the central subsidiary shrine, it was a representation of Siva's bull. ${ }^{58}$ In the case of Candi Prambanan, Krom was of the opinion that the buildings facing the main shrines were vāhana temples (Krom 1923: 486), an hypothesis that has often been repeated (for example Dumarçay 1993: 77), even though it was criticised as early as 1927 (Bosch 1927: 15-17). Bosch underlined that the Garuda standing in the northern temple had actually been brought from elsewhere and that the only sculpture to have been found within the ruins was a fragmentary statue of Śiva. Bringing to the fore that subsidiary shrines of Candi Badut and Ijo yielded a bull (in the centre) and a linga-yoni, ${ }^{59}$

57. Stanza 1: 26-28 are especially interesting (Robson 2015: 37-38):

26 He [Rssyaśrngga, the officiant] performed the ritual of empowerment,

The invocation and enthronement ceremonies;

He fixed his mind on the Highest Lord,

Present there in the fiery hearth.

27 When the Lord had been assigned his place,

Soma-like butter was sprinkled there,

As well as the black sesame and honey,

To join the resin and the firewood.

28 The holy hearth was worshipped:

Offerings surrounded it, with fish, meat and curds,

As well as rice as oblations to the gods,

Mixed with all manner of tasty things.

58. This was the case for instance at Prambanan, Ijo, Merak and Badut (Bosch 1927: 15-17).

59. Bosch actually also mentions Candi Merak, where a bull was found in the central shrine. He identifies the fragmentary statue found among the ruins of the southern building to be a representation of Śiva Mahāyogi and equates it with the linga found at Ijo and Badut. However, the statue is too damaged for this identification to be considered certain. 
Bosch concluded that this was a standard pattern in Central Java and that Prambanan was probably no exception. But he was unable to identify the focus of worship in the third secondary temple. Recent restoration work at Candi Ijo and the discovery of Candi Kimpulan allow us to complete the schema and to identify this last element as being a stone-lined pit - in which we propose to see a fire altar. At Ijo, the three subsidiary shrines facing the main temple respectively house a linga-yoni (left, i.e. south), a bull and a balipițha (centre) and a small square "tank" (right, i.e. north). Thus, we find there almost exactly the same pattern as at Kimpulan. ${ }^{60}$ The fact that there are three subsidiary temples at Candi Ijo and just one at Candi Kimpulan does not seem to be relevant from a structural point of view: they had the same ritual function. This possibility - that there is no significance difference between sanctuaries with three secondary shrines and those with only one - was already suggested by the layout of Candi Lawang (Boyolali), where the main temple faces a single elongated structure, but with three staircases. This leads us to question Krom's hypothesis about Candi Semar (the small building facing Candi Arjuna, on the Dieng plateau), which he thought was not a temple but a mere storing place for ritual objects (Krom 1923: 192). The rectangular ground plan of Semar - and of similar buildings at Gedong Songo - may suggest that it actually had the same function as Kimpulan's secondary shrine.

\section{The courtyard}

The two shrines of Kimpulan are standing in the middle of a courtyard measuring ca. $22.5 \times 22.5 \mathrm{~m}$ enclosed within a low wall made of river stones (figs. 1 and 18). The latter is $c a .1 .2 \mathrm{~m}$ thick but only $60-75 \mathrm{~cm}$ high. No traces of gates were found. Eight linga-shaped stone markers were discovered in situ within the courtyard; ${ }^{61}$ they were marking its centre and its corners as well as the middle of each side of the enclosure. ${ }^{62}$ Such markers are common in the Hindu sanctuaries of Java from the 9th century onwards. They probably served both ritual and practical purposes, delimitating the sacred space and facilitating the positioning of the structure within the courtyard (Dumarçay 1986: 23; 1993: 53; Degroot 2009: 171-174). At Kimpulan, however, these stones are not regularly placed, which might indicate that they were not used as reference points during the construction or that they were moved and misplaced subsequently. ${ }^{63}$

A couple of interesting finds were made within the courtyard. Near the northeastern stone marker was found an unfinished statue of Ganeśa.

60. Candi Sambisari most probably follows the same pattern. A yoni has been found among the ruins of the southernmost/left secondary shrine, a balipittha was discovered near the central shrine - and another one in the direct surroundings. No bull was reported, but the edge of what may have been a pit is visible at the surface of the pavement of the northern shrine.

61. Just as the main linga, these stones have a square bottom section and a circular top section; they miss the octagonal element.

62. The ninth such stone should have been located in the southeastern corner but was not recovered.

63. Since they were found standing upright, we must exclude a natural cause. 


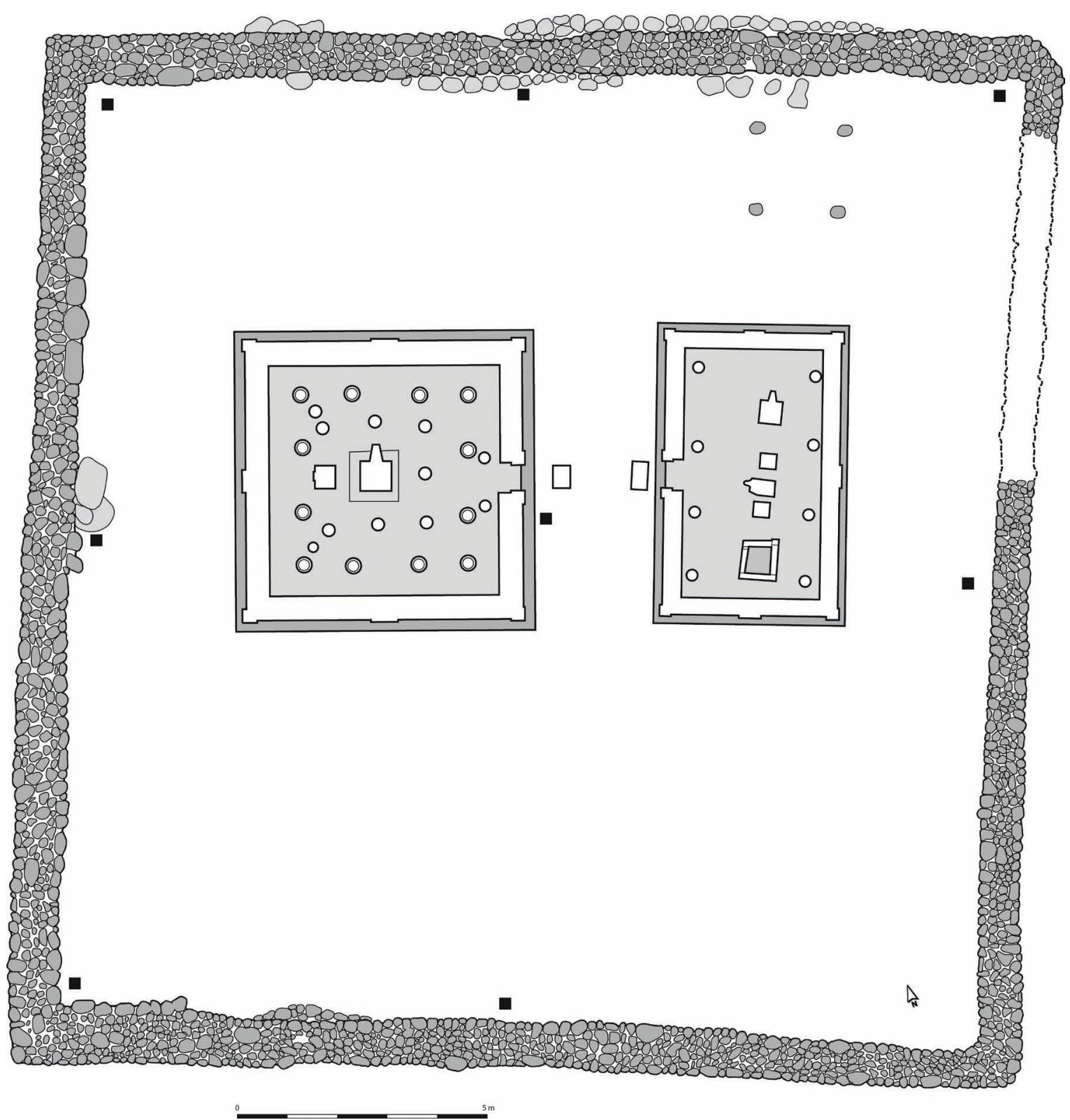

Fig. 18 - Candi Kimpulan. General layout of the courtyard and stone markers (adapted from Gambar No. YEL02P06482, BPCB DIY, 2010).

Directly to the west of the sculpture, one can see four small round stones arranged in a square of $1.5 \times 1.5 \mathrm{~m}$ (fig. 18). Their concave upper surface suggest that they were meant to support round horizontal beams - possibly bamboo poles - and are most probably remnants of a small shed or a bale-bale. ${ }^{64}$

64. A small raised resting platform made of wood or bamboo. 


\section{Ritual deposits at Candi Kimpulan: material remains of installation and consecration ceremonies}

Candi Kimpulan is exceptional in many respects, but its most striking feature is its excellent state of preservation. Unlike the majority of temples - that were slowly abandoned and exposed to looting - Candi Kimpulan was buried under volcanic materials while it was still an active place of worship. ${ }^{65}$ The temple was never vandalised, which means that the peripih (ritual deposits) were found intact. It is, at the time of writing, the only temple in Southeast Asia that has yielded a complete set of ritual deposits. Offerings were found, within the yoni, beneath the pavement and beneath the pillars.

\section{The linga-yoni}

The first ritual deposit that was found in Candi Kimpulan had been placed within the yoni, directly beneath the linga (fig. 19). The objects composing the peripih were placed within a small stone casket measuring $17 \times 17 \times 5.6 \mathrm{~cm}$, without lid - the linga itself being used as a cover (fig. 20). Seventeen cavities had been cut out in the casket: a circular cavity (ca. $5 \mathrm{~cm}$ in diameter) in the centre, surrounded by eight smaller petal-shaped cavities and, in between, eight tiny rectangular holes ( $c a .1 \mathrm{~cm}$ long). The objects deposited in the central cavity were especially varied. Placed one upon the other were found a circular gold plate engraved with an eight-petal lotus, a rectangular silver leaf engraved with a 9-square grid and some akșaras in Kawi script, an inscribed rectangular gold leaf and, above it, 20 silver $m \bar{a}$-coins of different sizes, 2 smaller gold $m \bar{a}$-coins (diam $0.6 \mathrm{~cm}$; 18 carat), as well as 13 small pieces of gold foil (figs. 21 and 22). Deposits in the petal-shaped cavities comprised gold and silver foils. ${ }^{66}$ The tiny rectangular cavities between the petals were empty, with the exception of the one located in the east-northeast, which contained an oval-shaped piece of bronze. Below the stone casket, in a thin layer of sand, were found several strips of gold foil, a blue glass bead, a blue cabochon and a gold $m \bar{a}$-coin, as well as a fragment of a second gold coin.

The casket and its contents are most likely material traces of the ceremony of installation of the linga, a ritual that includes the "deposit of jewels" (ratnayāsa). The ratnayāsa is mentioned in several textual

\footnotetext{
65. There are, in Central Java, other examples of temples that have been buried by lahars. Sambisari and Kedulan are two well-known cases. But these temples have been buried by successive lahars over several centuries. At Sambisari, the main volcanic deposit is dated to the 15 th century. As the ancient culture was already fading while the temples were still partly visible, they were exposed to looting. In both cases, the central temple pit had already been dug out by looters prior to their excavation by the Puslit Arkenas and the BPCB.

66. Only gold foil fragments were found to the northwest and southeast. Other cavities contained both gold and silver foils. Deposits in the north, northeast, east and southwest cavities were slightly richer than those placed in the western and southern ones. This, added to the fact that the only tiny cavity to contain a deposit was located in the east-northeast, might suggest that the northeast had a specific importance.
} 


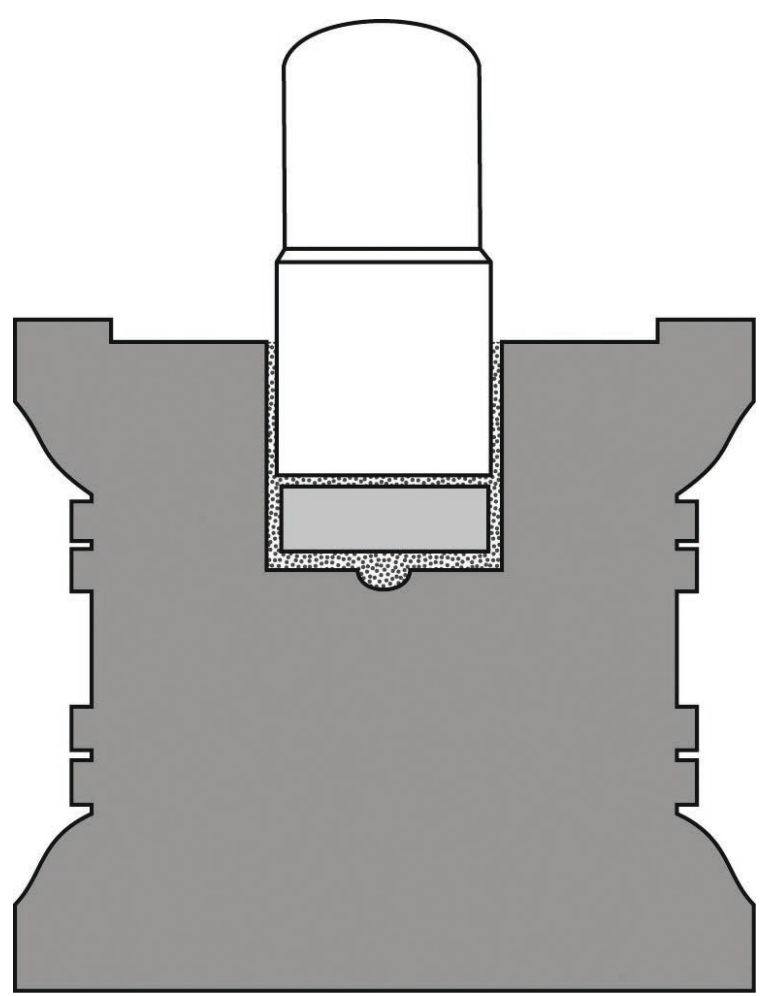

Fig. 19 - Candi Kimpulan. Main temple. Cross-section of the linga-yoni pedestal, with position of the peripih box.

> Fig. 21 - Candi Kimpulan. Main temple. Lotus engraved on a gold plate, found in the peripih box within the linga-yoni pedestal (central cavity) (BPCB DIY; photo: BPCB DIY).

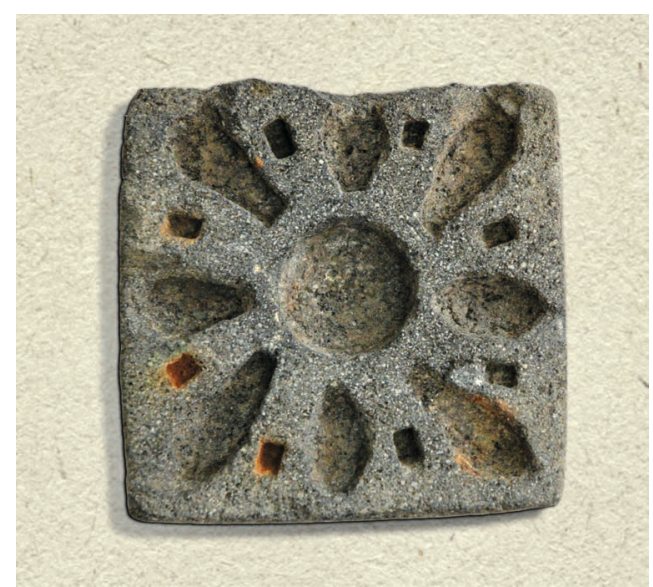

Fig. 20 - Candi Kimpulan. Main temple. Ritual deposit box found within the linga-yoni pedestal (Universitas Islam Indonesia; photo: V. Degroot/EFEO).

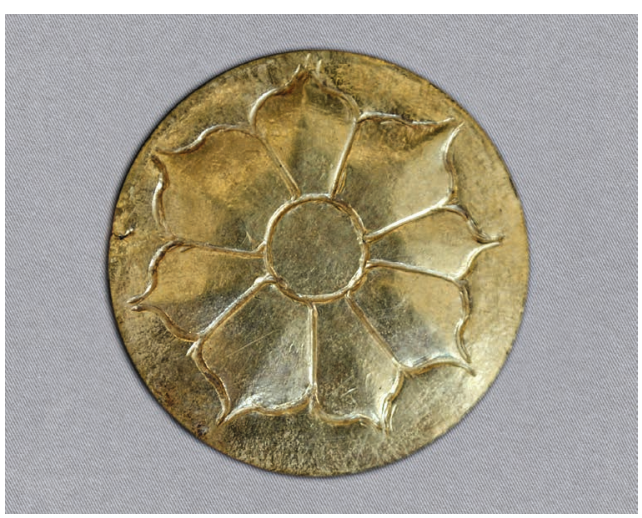

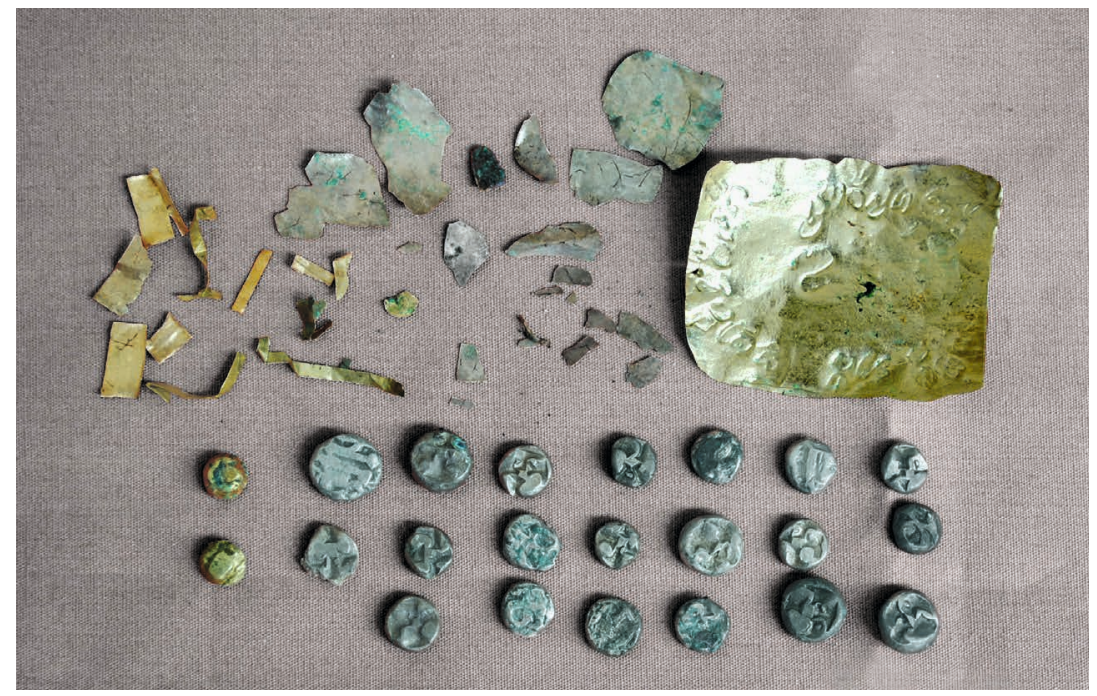

Fig. 22 - Candi Kimpulan. Main temple. Contents of the central cavity of the peripih box within the linga-yoni pedestal - the only missing item is the lotus (see fig. 21) (BPCB DIY; photo: BPCB DIY). 
sources from India, ${ }^{67}$ although its material implications are not always clearly specified and it is sometimes confused with the temple consecration ritual. According to Sanskrit texts belonging to the corpus of Śaiva àgamas, a stone (brahmaśilā, ādhāraśilā) with a mortise and nine cavities was placed at the centre of the cella. After offerings had been placed in the cavities, the linga would have been fitted into the mortise and the pedestal installed (Brunner 1993: 94-95; Barazer-Billoret 1993-1994: 58-60) ${ }^{68}$ According to these texts, the pedestal was thus put in place after the linga, being lifted above the linga and gradually descended - which presupposes that the yoni pedestal was ring-shaped. At Candi Kimpulan, as almost everywhere on Java, the pedestal was not bored through and the chronological order of the installation must have been reversed. A pavement of $1 \times 1 \mathrm{~m}$ was first laid, after which the pedestal was placed and offerings were made, it is only then that the linga was descended into the yoni.$^{69}$ The compartmented stone casket within the yoni's shaft played the role of the brahmasilia of Indian texts, receiving the offerings and supporting the linga. ${ }^{70}$ In Kimpulan as in the prescriptive Sanskrit literature, the offerings deposited within the central cavity are more complex and richer than those in the periphery. But it is almost the only similarity. While Indian texts suggest to place three series of nine objects - i.e. three different substances in each cavity, the Kimpulan offerings are almost undifferentiated: gold and silver everywhere, but not in the form, and without any (semi-)precious stones ${ }^{71}$ However, Candi Kimpulan being the only Indonesian temple with an intact pedestal deposit, we should refrain from concluding that this simplicity is a Javanese characteristic. It might as well be due to the fact the Kimpulan is a small sanctuary, more likely to be linked to a local than to a royal foundation.

\section{Beneath the pavement around the pedestal}

When, during restoration works, the pavement of the main temple was removed to place a draining system, several other ritual deposits were found beneath and around the yoni pedestal, beneath the statue of Ganeśa and below the pillar bases (figs. 7 and 23).

67. For a list to the Sanskrit texts mentioning the ratnayāsa and a discussion of this ritual as described in the Devyāmata, see Ślączka 2017.

68. In a recent paper, Dominic Goodall suggests that this part of the installation ritual was not of foremost importance in early Śaiva traditions (Goodall 2017: 55-56).

69. The inversion of the chronology of the installation might have had a symbolic significance. Whereas in the Indian aggamas the emphasis is on the linga as an irremovable pillar, in Javanese practice, it becomes a movable element. But it might, at the same time, reinforce the phallic character of the linga, perceived as penetrating the yoni. Moreover, naturalistic lingas are not unheard of in Java.

70. Such pedestal deposits are not unique to Java. Stone caskets meant to fit a pedestal shaft have been found in Cambodia as well, notably at Pre Rup and Preah Khan. See Ślączka 2007: pl. 19-20.

71. The Rauravāgama (30.41-46), for instance, states that a sapphire, mustard seeds and antimony must be placed in the southern cavity, while the northern cavity should contain a cat's eye, millet and pyrite. See Barazer-Billoret 1993-1994: 59 n. 58. 


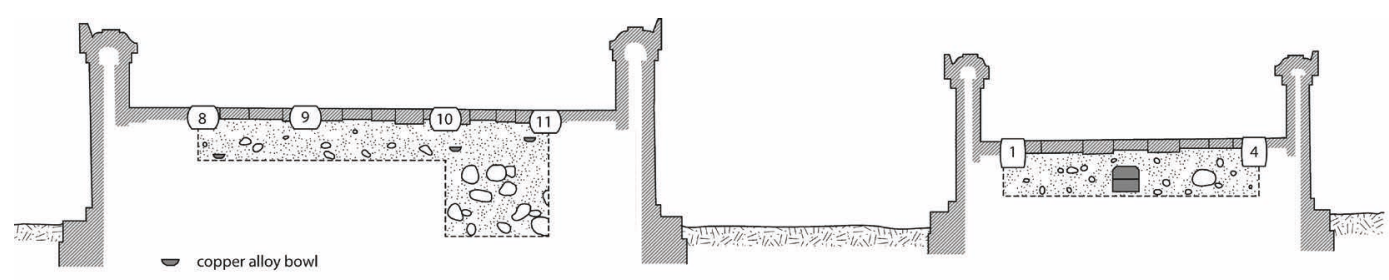

\section{A}
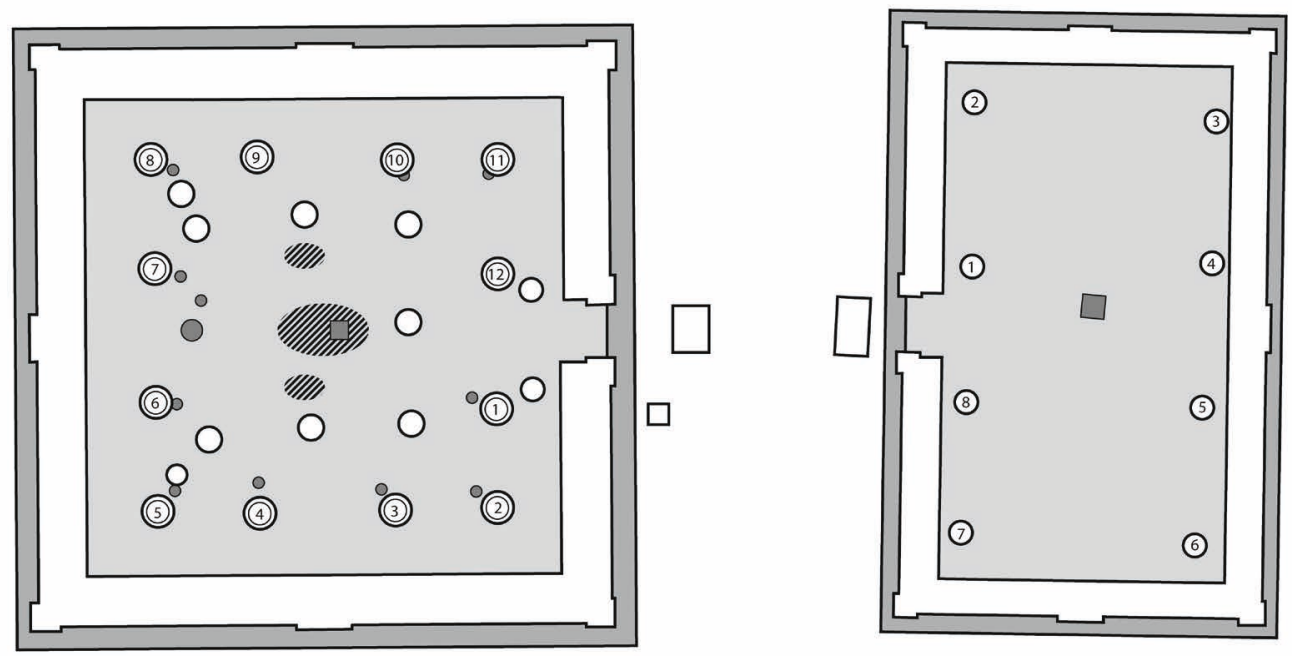

- copper alloy bowl/plate

peripin casket

ritual deposit without container

Fig. 23 - Candi Kimpulan. Plan and cross-section with location of the peripih (adapted from Gambar Nos. YEL02P06347, YEL02P06348 and YEL02P06350, BPCB DIY, 2010).

A stone casket was unearthed at the centre of the temple - more or less beneath the yoni pedestal, ca. $65 \mathrm{~cm}$ below the surface of the pavement. ${ }^{72}$ It is a square box, measuring $22 \times 22 \times 10 \mathrm{~cm}$, with a lid (fig. 24). ${ }^{73}$ The cavities are smaller than in the case of the peripih casket found within the yoni, but they are elegantly designed. The central cavity is circular and surrounded by nine pointy petal-shaped cavities, resembling pipal leaves. All cavities were filled with fine soil, except the southwestern one, where a fragment of copper alloy was found. No traces of plant material were discovered. Around the stone casket,

72. This measure corresponds to the base of the stone casket. The peripih box was located ca. $20 \mathrm{~cm}$ to the east of the geometrical centre of the terrace, thus not directly under the yoni which was off-centre to the west.

73. The lid measures $22 \times 22 \times 9 \mathrm{~cm}$.

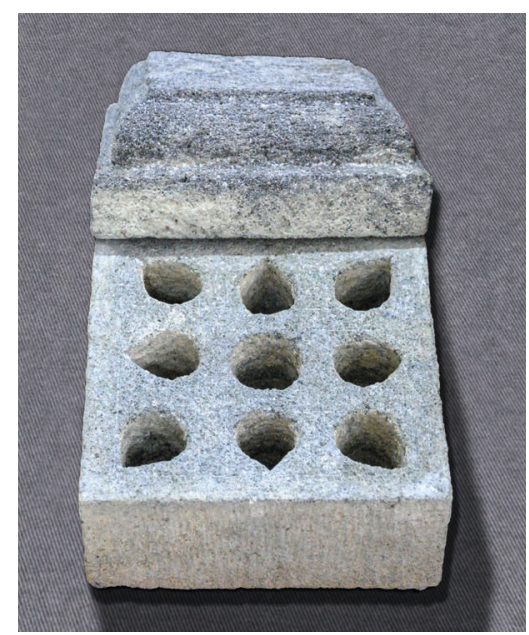

Fig. 24 - Candi Kimpulan. Main temple. Central peripih casket (Universitas Islam Indonesia; photo: V. Degroot/ EFEO). 
mixed with the soil, were also discovered fragments of small iron spatulas,${ }^{74} \mathrm{a}$ few sherds of a copper alloy bowl, a small copper alloy ring, ${ }^{75}$ pieces of silver and gold foil, as well as two small blue cabochons. ${ }^{76}$ East of the casket were found fragments of iron spatulas, ${ }^{77}$ as well as gold strips and gold foil (fig. 25). ${ }^{78}$

Similar deposits were found to the north and to the south of the casket but at a slightly higher level. To the north fragments of iron spatulas, ${ }^{79}$ a copper alloy bowl, ${ }^{80}$ one small gold strip, ${ }^{81}$ two blue cabochons ${ }^{82}$ as well as 5 glass beads $;{ }^{83}$ to the south fragments of iron spatulas, ${ }^{84}$ a copper alloy bowl, ${ }^{85}$ fragments of gold strips, ${ }^{86}$ one gold ring ${ }^{87}$ and two small blue cabochons. ${ }^{88}$

\section{The Ganeśa statue}

One of the largest and most complex ritual deposits was found almost plumb below the Ganeśa, at some 60-70 cm below the pavement (figs. 7 and 26). Inside a copper alloy plate ${ }^{89}$ were discovered fragments of iron spatulas, ${ }^{90}$ one bronze bangle, ${ }^{91}$ one small copper alloy mirror, ${ }^{92}$ fragments of gold foil, six short gold strips, a fragment of silver foil, a gold ring, ${ }^{93}$ three blue cabochons, ${ }^{94}$ a brown bead, ${ }^{95}$ a tiny fragment of crystal and a silver bowl. ${ }^{96}$ The latter contained a flower made of two layers of silver foil and one layer of gold foil, ${ }^{97}$ as well as fragments of gold foil.

74. All spatulas were heavily corroded. Their approximate length (handle included) must have been $10 \mathrm{~cm}$, i.e. slightly smaller than a teaspoon. The fragments found beneath the yoni amount for $30 \mathrm{~g}$ and at least 23 individual items. Although we have not found reference to similar finds in the literature, iron spatulas (presumably from Candi Plaosan) are exhibited in the small site museum of Candi Sewu. 75. The ring is $1.7 \mathrm{~cm}$ in diameter. It is a plain copper alloy wire curled in the shape of a ring.

76. Of $c a .1 \mathrm{~cm}$ in diameter.

77. Around $38 \mathrm{~g}$ and at least 21 individual items.

78. Three fragments of gold foil and 9 fragments of thin gold strips (some of them twisted). All smaller than $2 \mathrm{~cm}$.

79. For a total of $23.6 \mathrm{~g}$ and at least 18 individual items.

80. The bowl was already broken. Its diameter is estimated to have been slightly above $10 \mathrm{~cm}$.

81. Curled in to form a half circle (diam.: $0.8 \mathrm{~cm}$ ).

82. Actually, one cabochon (diam.: $0.5 \mathrm{~cm}$ ) and one fragment of cabochon, possibly of similar dimensions.

83. One red, one white and three dark blue beads.

84. For a weight of $30 \mathrm{~g}$ and at least 23 individual items.

85. It was broken into a dozen of tiny fragments and its diameter could not be restituted.

86. Eight fragments. The smallest is $2 \mathrm{~mm}$ long, the longest about $2 \mathrm{~cm}$. Most of them are twisted.

87. It is actually made of a plain gold stripped, curled in so to form an open ring (diam. $0.8 \mathrm{~cm}$ ).

88. Diam.: $0.8-0.9 \mathrm{~cm}$.

89. Diam.: ca. $21 \mathrm{~cm}$; found broken in pieces but still in situ.

90. For a total of $35 \mathrm{~g}$ and at least 22 individual items.

91. Diam.: $5.3 \mathrm{~cm}$.

92. Plain. Diam.: $9 \mathrm{~cm}$. Height: $16.5 \mathrm{~cm}$. Strangely enough, the handle is flat, which lets think that it was made for ritual purposes and not used in real life.

93. As the previous ones, it is made of a gold strip shaped into an open ring.

94. Diam.: $0.7 \mathrm{~cm}$

95. Cylindrical. Diam.: $0.7 \mathrm{~cm}$. Length: $1 \mathrm{~cm}$.

96. Diam.: $13 \mathrm{~cm}$.

97. Each layer counts 4 petals. The flower is $c a .8 \mathrm{~cm}$ in diameter. 
Fig. 25 - Candi Kimpulan. Main temple. Some of the objects found around the stone casket beneath the pedestal: gold foil and gold strips, cabochon, bead, gold coin, silver foil, bronze fragment and iron spatulas (BPCB DIY; photo: BPCB DIY).

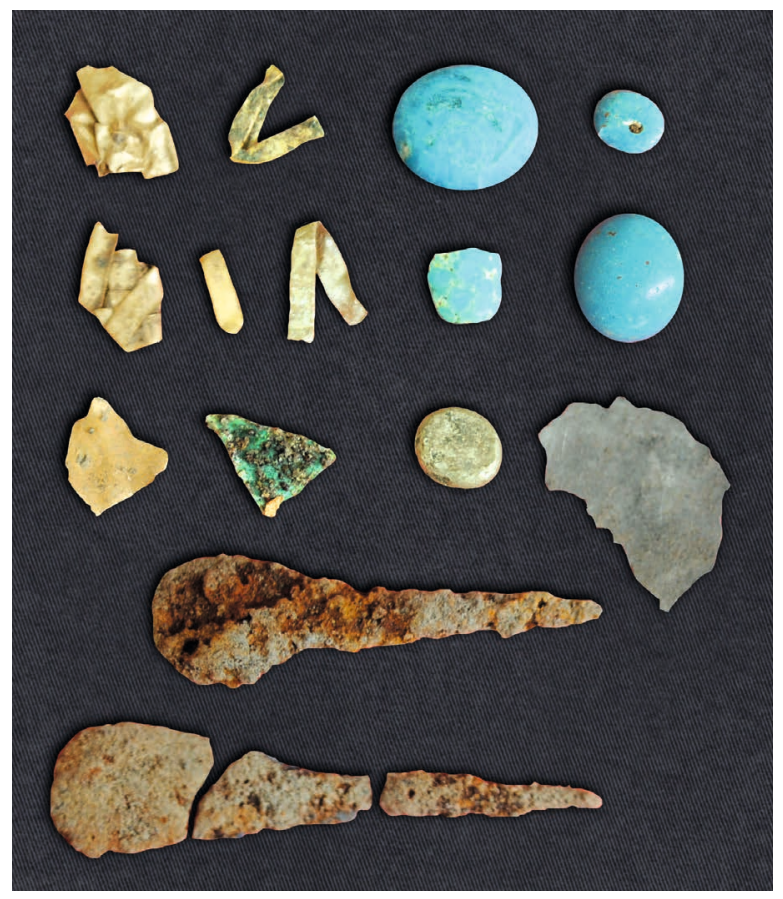

Fig. 26 - Candi Kimpulan. Main temple. Ritual deposit beneath the Ganeśa. Bronze plate (left), bronze bowl (right) and iron spatulas (photo: BPCB DIY).

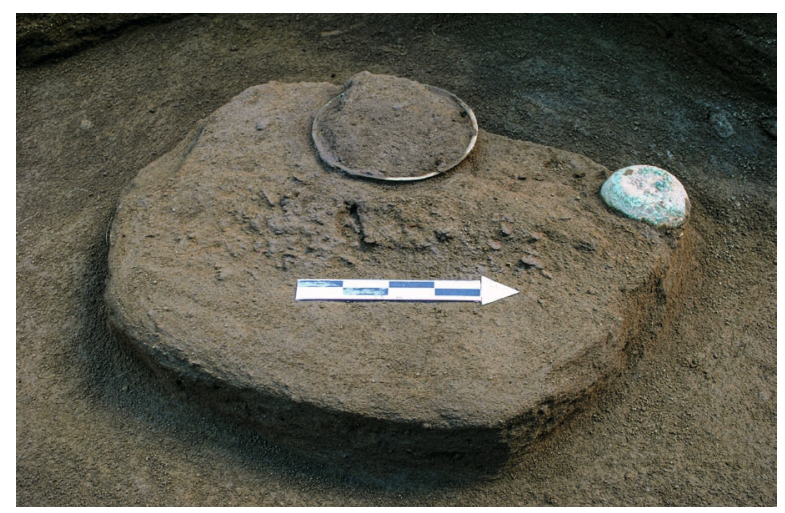

Outside the plate, but consistently at $60-70 \mathrm{~cm}$ below the pavement, many other objects - parts of the same deposit - were unearthed, namely fragments of iron spatulas, ${ }^{98}$ a bronze ring, ${ }^{99}$ two tiny fragments of bronze, fragments of gold foil and gold strips, two gold rings, ${ }^{100}$ two small blue cabochons, ${ }^{101}$ six glass beads, ${ }^{102}$ a few pieces of charcoal and a copper alloy bowl placed upside down above iron spatulas. ${ }^{103}$

98. Around $400 \mathrm{~g}$ and at least 258 individual items.

99. Plain. Diam.: $3.2 \mathrm{~cm}$. Possibly a toe ring.

100. Plain gold strips rolled into open rings. Diam.: 0.6 and $0.8 \mathrm{~cm}$.

101. Diam.: $0.9 \mathrm{~cm}$.

102. Two blue beads, two yellow, one dark blue and one light green.

103. The bowl opening has a diameter of $c a .12 \mathrm{~cm}$. There were at least 14 spatulas, with a total weight of $18.4 \mathrm{~g}$. 


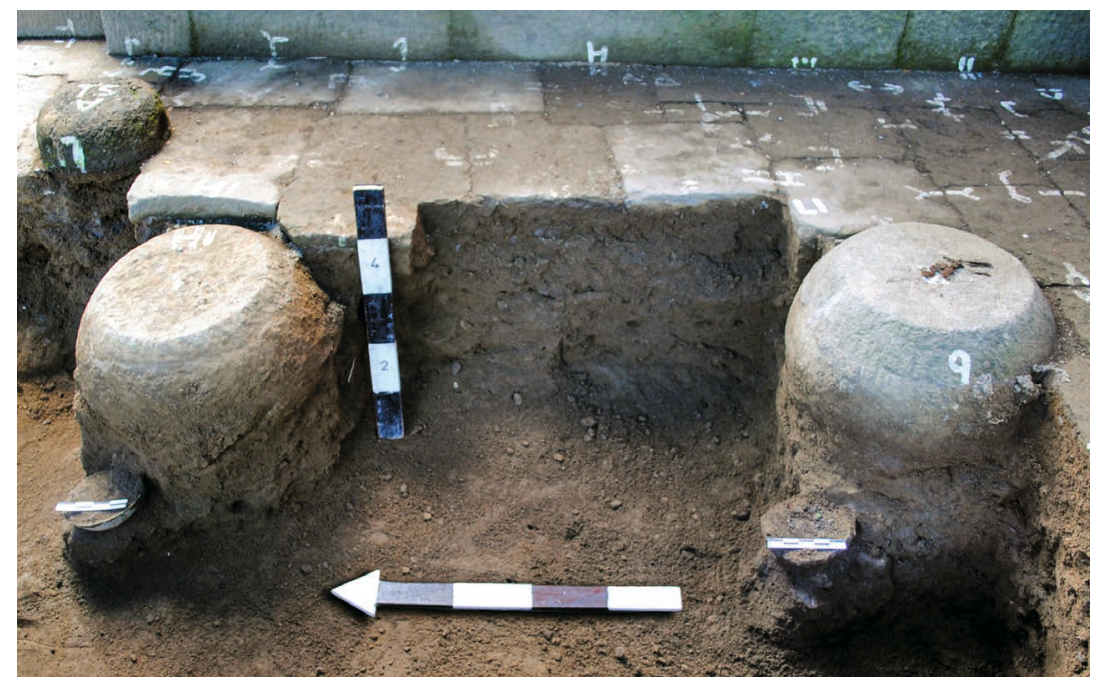

Fig. 27 - Candi Kimpulan. Main temple. Bronze bowls near the base of pillars 1 and 2 (photo: BPCB DIY).

\section{Beneath the pillar bases}

Simpler ritual deposits, composed of a small bronze bowl and iron spatulas, have been found below the large pillar bases (figs. 23 and 27). ${ }^{104}$ The deposits were placed $10-20 \mathrm{~cm}$ below the stones, i.e. $30-50 \mathrm{~cm}$ below the pavement. ${ }^{105}$ Most bowls have a lightly everted rim and a diameter of $10-13 \mathrm{~cm}$ but they are not identical. The bowl found under stone 4 has a straight rim. Even though the exact number of spatulas is difficult to evaluate, there seems to be a great variation between the deposits: only four spatulas were found near stone 10 , but more than twenty were unearthed below stones 6,8 and $11 .{ }^{106}$ Fragments of gold foil, beads and pottery sherds were occasionally found but it is difficult to determine whether these are voluntary deposits. ${ }^{107}$ They may have been brought with the soil used to fill the structure. ${ }^{108}$ Various other loose finds were made while dismantling the pavement, including iron spatulas, fragments of gold foil, a couple of beads and a gold $m \bar{a}$-coin.

104. With the exception of one of the stones of the northern rows (no. 9), where only spatulas have been found.

105. They were not exactly at the plumb of the pillar bases; they were shifted towards the inside of the temple.

106. Stone 1 at least 10 spatulas ( $16 \mathrm{~g})$; stone 2 at least 9 spatulas $(10 \mathrm{~g})$; stone 3 at least 15 spatulas (29 g); stone 4 at least 13 spatulas (22 g); stone 5 at least 17 spatulas (19 g); stone 6 at least 25 spatulas $(35 \mathrm{~g})$; stone 7 at least 8 spatulas $(11 \mathrm{~g})$; stone 8 at least 7 spatulas $(13 \mathrm{~g})$; stone 9 at least 3 spatulas ( $2 \mathrm{~g}$ ); stone 10 at least 4 spatulas ( $\mathrm{g}$ ); stone 11 at least 24 spatulas ( $44 \mathrm{~g}$ ); stone 12 at least 4 spatulas $(4 \mathrm{~g})$.

107. Fragments of gold strips (less than $1 \mathrm{~cm}$ long) were reported near stones 1, 3, 4, 8, 10 and 12 ; beads were found near stones 2, 6 and 11; pottery sherds near stones 1,3 and 5 .

108. The gold strips, sherds and beads were found outside the bowls, mixed with earth. With the exception of the blue glass beads from stone 2 and the dark blue beads from stone 22, which were found within the bowl and are thus more likely to have been placed there intentionally. 


\section{Chronological sequence of the deposits within the main temple}

If we look at the deposits from a stratigraphic point of view, it is possible to reconstruct their chronological sequence. The first offerings to be made were the central stone casket (and accompanying materials), the spatulas and gold fragments right to the east of it, and the deposits below the Ganeśa statue. This first set of ritual deposits was covered with a $10-20 \mathrm{~cm}$ thick soil layer. Thereupon the other offerings were installed - north and south of the central casket, as well as beneath the pillars. The ground was then levelled and the pillar bases, the foundation stone for Ganeśa's pedestal and the central pavement were set up.

The first deposits to be placed - beneath the Ganeśa and the yoni - are also the richest in terms of quantity and variety of offerings. The importance of the central peripih was to be expected. This is, in Java, the usual location for the temple consecration deposit. The latter is an essential element of a ritual known in Indian texts as garbhanyāsa - the placing of the embryo. The deposit is perceived as the life-breath of the temple and is supposed to bring prosperity to human beings ${ }^{109}$ However, the existence of a large ritual deposit to the west, beneath the statue of Ganeśa, had never been documented. This deposit is more complex than the central one and compares only with the offerings placed within the yoni pedestal. The timing of its installation is somewhat puzzling: it was made at the same time as the garbhanyāsa deposit, well before the sculpture was erected. This most probably means that, from the very beginning, Candi Kimpulan was conceived as a temple to Siva and Ganeśa, the latter being given almost the same importance as the former. In Java, as in India, Ganeśa, the remover of all obstacles, was a very popular divinity. The fact that Ganeśa was actually more important than other divinities of the Javanese triad is attested by the many sculptures of the god, exceeding by far the number of representations of Durgā and Agastya. It is also visible at Candi Gebang, where a yoni was placed in front of the sculpture of Ganeśa - probably to receive offerings - while the other statues did not benefit from a similar fitting out. Ganeśa is - besides Siva - possibly the only Hindu deity to which temples were dedicated. ${ }^{110}$ Its importance within the religious landscape of Java is also observable at Dawangsari, where a monolithic statue of the god was erected and in the vicinity of which an inscription related to his worship was found. ${ }^{111}$ Furthermore, several other large free-standing statues of Ganeśa dating to the Central Javanese period seem to suggest that the cult of the elephant god had increased in favour by the end of 9th century. ${ }^{12}$

109. For a discussion about the meaning of the garbhanyāsa, see Ślączka 2007: 201-215.

110. In Central Java, the now vanished temples of Setan (Magelang) and Sikunir (Semarang) were probably dedicated to Ganeśa (Krom 1923: 222-223, 408). The extremely large dimensions $-170 \mathrm{~cm}$ - of the Ganeśa of Simangli (Batang) and the fact that no linga-yoni pedestal was found in this somewhat remote place let also think that Ganeśa may have been the main deity to be worshipped. 111. For a transcription of the latter inscription, see Riboet Darmosoetopo et al. 2015: 52-57. For a discussion of the inscription and a photo of the statue, see Griffiths 2011. About Ganeśa statuary in Java during later periods, see Edi Sedyawati 1994.

112. The Ganeśa statues bearing an inscription on their back were obviously free standing. This is the case of the Ganeśas of Balingawan (891 CE), Ketanen (904-905 CE), Kinewu (907 CE) and Pare 
The stratigraphic relationship between the central ritual deposit and the offerings beneath the statue may also suggest that the latter ones were not mere installation deposits but played a part in the garbhanyāsa ritual as well. Few texts clarify the meaning of this ritual, but some authors suggest that, besides being life-bringers, ritual deposits were markers, used to separate and protect the sacred space from the profane (Ślączka 2007: 207-208). In the way the various deposits were placed in Candi Kimpulan, one may detect a certain desire to appropriate space by marking the centre (the stone casket), the east-west axis (Ganeśa and east deposits), the secondary axis (northern and southern deposits) and the periphery (pillar deposits). ${ }^{113}$

\section{Ritual deposits from the secondary shrine}

Ritual deposits were also discovered during restoration works in the secondary shrine and in the temple courtyard. As in the main temple, the installation of the linga on its pedestal was preceded by the placement of a compartmented stone casket within the yoni's shaft. This peripih container measures $15.5 \times 15.5 \times 5.3 \mathrm{~cm}$ and is almost identical to the one from the main temple: the circular cavity is surrounded by eight petal-shaped cavities and eight small rectangular holes are found between the petals. The central cavity yielded two glass beads (one grey, one blue), two twisted gold strips and two shreds of copper alloy. In the northern cavity were found two blue cabochons; in the northeastern one, two beads (one yellow, the other white). All the remaining cavities were empty or, to be more precise, filled with earth and sand. Beneath the peripih casket, in a small round hole, were found three shreds of copper alloy and one tiny piece of gold foil.

A second stone casket was found upon the dismantling of the pavement, $30 \mathrm{~cm}$ below the surface, at the centre of the terrace (fig. 28). ${ }^{114}$ It measured $24.5 \times 24.5 \times 13 \mathrm{~cm}$ (with lid). ${ }^{115}$ Inside this stone box were found iron spatulas, ${ }^{116}$ rice husks, two fragments of gold foil, seven silver coins, ${ }^{117}$ two fragments of white glass, one brown cabochon, one fragment of copper alloy, and eleven glass beads. ${ }^{118}$ Dozens of iron spatulas, ${ }^{119}$ one blue cabochon, three beads ${ }^{120}$ and six bronze shreds were unearthed in the direct

(908-917 CE). These four inscribed sculptures, although dating from the Central Javanese period, have been found in East Java. About the inscriptions, see Sarkar 1971: nos. 56, 57, 75; Nakada 1982 I/73, I/88, I/101; Edi Sedyawati 1994: 322-324; Machi Suhadi \& Richadiana 1996: no. 2.4.8.

113. From a religious point of view, the axis marking the sunrise and the sunset is the most significant one. Indian treatises on architecture agrees that, generally speaking, temples must face either east or west. From a practical point of view, it is also the first centreline to be placed when building the temple, using the gnomon technique. The north-south axis is extrapolated from the east-west axis. In the same manner, offerings were first made on the east-west axis and only afterwards on the other one.

114. Thus not below the bull's statue, but in between Śiva's mount and the northern balipit tha.

115. The lid had identical dimensions.

116. At least 28 spatulas / $41 \mathrm{~g}$.

117. Five of them are of the usual type ( $m \bar{a}$-coins), two are triangular in shape.

118. Three yellow, two light green, two dark blue, two white and two light blue beads.

119. At least 95 spatulas / $200 \mathrm{~g}$.

120. One dark blue bead, one elongated green bead and one double golden bead. 


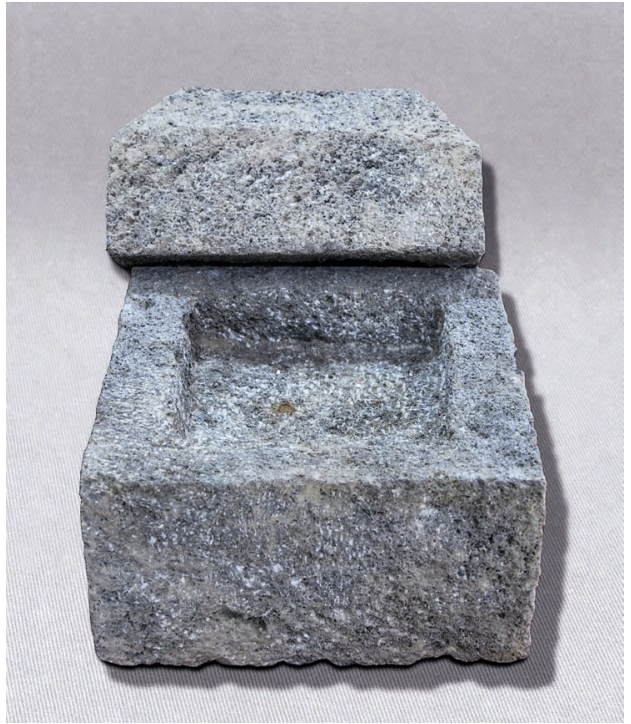

Fig. 28 - Candi Kimpulan. Secondary temple. Central peripih casket (Universitas Islam Indonesia; photo: V. Degroot/EFEO).

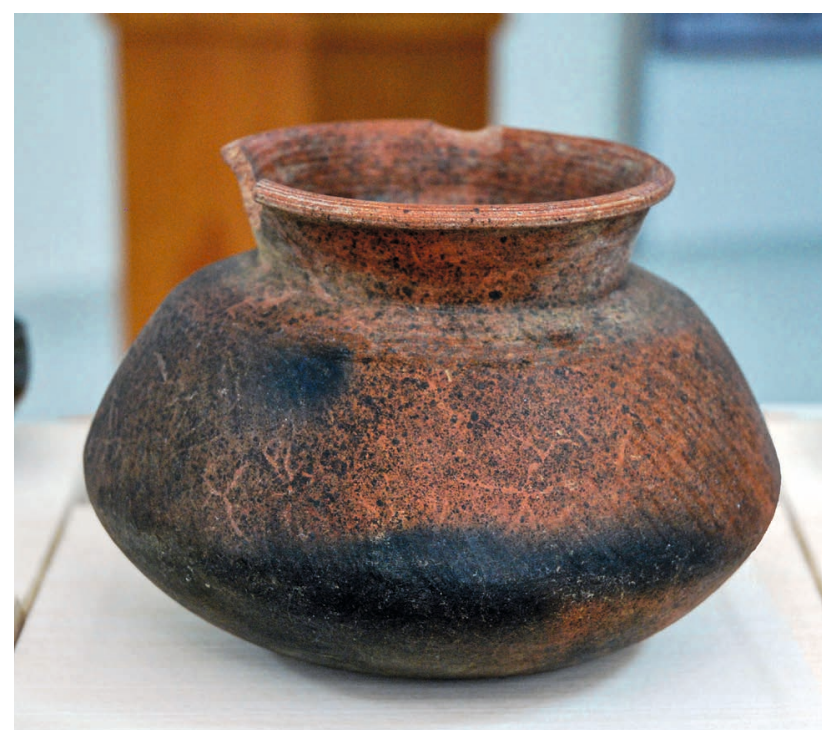

Fig. 29 - Candi Kimpulan. Earthen pot found west of the courtyard, outside the enclosure wall (Universitas Islam Indonesia; photo: V. Degroot/EFEO).

vicinity of the casket. Under each of the pillar bases were found spatulas and pottery sherds. ${ }^{121}$

\section{The courtyard}

As mentioned at the beginning of this article, the placing of drainage pipes to prevent the inundation of the courtyard required the ground to be excavated in several places. These works have led to the discovery of several earthen pots, buried on purpose below the ancient ground level. Four pots, filled with fine soil, have been found between the main temple and the secondary shrine. ${ }^{122}$ Three other pots were unearthed respectively to the south, west and north of the main temple - though not regularly placed. They were found in association with bronze fragments and iron spatulas. ${ }^{123}$ At least one other pot was found outside the courtyard, $34 \mathrm{~m}$ to the west of the central marker; it contained iron spatulas (fig. 29). All the pots share the same profile. ${ }^{124}$

121. Stone 1: 2 spatulas $(2 \mathrm{~g}), 3$ sherds. Stone 2: 1 spatula $(0.5 \mathrm{~g})$. Stone $3: 1$ spatula $(0.5 \mathrm{~g})$, 3 sherds. Stone 4: 1 blue bead. Stone 5: 4 spatulas $(1.5 \mathrm{~g}), 1$ sherd, 1 charcoal. Stone 6: 1 spatula $(1 \mathrm{~g}), 6$ sherds (possibly from a kendi). Stone 7: 2 spatulas $(1 \mathrm{~g}), 9$ sherds. Stone 8: 3 sherds. To these, one must add loose finds discovered during the dismantling of the pavement, including 12 iron spatulas $(20 \mathrm{~g})$ and a couple of sherds.

122. One was found in association with fragments of bronze, possibly from a small plate or a mirror.

123. In addition to the bronze and iron, a yellow and a white bead were found near the pot in the north.

124. Two pots are complete, the other ones could only be partially reconstructed. Their estimated measurements are: height $12-13 \mathrm{~cm}$, outside aperture $11-13 \mathrm{~cm}$, diameter at neck level $7.5-9 \mathrm{~cm}$, maximum diameter (at carination level) $17-19 \mathrm{~cm}$, wall thickness $c a .0 .5 \mathrm{~cm}$. 
They are small red earthenware with a convex bottom, a slight carination, a constricted opening and a slightly everted lip. The body was shaped using the paddle and anvil method. ${ }^{125}$ They bear horizontal traces of smoothening as well as of decorative burnishing.

\section{Ritual deposits in context}

As we have seen, the ritual deposits found in Candi Kimpulan are linked to two different rituals, namely the ratnanyāsa (deposit of the jewels, i.e. installation of a statue/linga) and the garbhanyassa (deposit of the embryo, i.e. temple consecration). Whereas these rituals take place at different times, they share the same primary purpose of installing the life-breath within the temple and stimulating prosperity among the people. This explains the similarities in the offerings, which represent the riches of the earth (gems, jewels, fertile soil, seeds, etc.). Above, we have already said a few words about the ratnanyāsa in Indian texts. In the following paragraphs, we would like to explore the material aspects of the garbhanyāsa at Kimpulan and briefly compare it with other Hindu sites from Central Java and with Indian textual traditions. ${ }^{126}$

At Candi Kimpulan, the garbhanyāsa ritual involved the placing of a stone box at the centre of the temple and bronze bowls as secondary deposits at the periphery below the pillar bases. The presence of a stone casket at the centre of the temple seems to have been the rule in Central Java. Even though few peripihs have been found in situ, ${ }^{127}$ the (empty) temple pits and the many stone boxes with lids ${ }^{128}$ that have been discovered lying among the ruins are proof enough of the wide dissemination of this tradition. ${ }^{129}$ Placing ritual deposits at the periphery, might not have been done systematically, ${ }^{130}$ but is nevertheless documented at Candi Prambanan, ${ }^{131}$

125. The neck and lip may have been wheel-shaped before being pasted to the body.

126. Much of the textual and comparative data is drawn from Ślączka's seminal work (Ślączka 2007).

127. Ritual deposits boxes were found in the central shaft of the following temples: Candi Prambanan (Śiva temple, Viṣnu temple, secondary shrine II/I), Ijo, Sampangan, Gatak, Kadisoka, Ngempon and Gedong Songo. See Soekmono 1995: appendix I; Ślączka 2007: appendix IV; Degroot 2009: appendices 2-3. Information about the peripih found at Gedong Songo comes from the archives of the BPCB Jawa Tengah (Prambanan).

128. Until now, peripih boxes with or without lid have been regarded by archaeologists as being the same thing. It was supposed that the lids simply got lost. The Kimpulan findings suggest that some of these stone caskets may never have had a lid, simply because they were meant to be placed inside the pedestal and sealed by the installation of the linga.

129. This tradition was also well known to looters, since most temple shafts have been dug out long before archaeologists got a chance to excavate them.

130. It is difficult to assess its real frequency. Since the deposits are made within the wall or the base, the peripih are only discovered when the structure is dismantled for restoration.

131. Several shrines of the Prambanan temple complex have yielded peripih, but published data are scarce. Ritual deposits - bronze pots - have been found within the walls of Candi Wisnu, in the east, southeast, southwest, northwest, north and northeast directions (Soenarto 1985). Similar deposits were discovered in the southeast and northeast corners of Candi Siwa (Soekmono 1995: appendix I; Ślączka 2007: appendix IV). Two stone containers were also discovered within the walls of Candi Brahma (Soekmono 1995: appendix I; Ślączka 2007: appendix IV). In 2016, while 
Sambisari and Dwarawati (Dieng) (Soediman 1976; Soenarto 1985; Anom 1985; Ślączka 2007: 325-326, 328-329). ${ }^{132}$ The layout of the peripheral deposits at the two latter temples bears close similarities with the pattern observed at Kimpulan: the cella was surrounded by twelve deposits and the containers were mostly bronze pots and bowls. At Sambisari, the deposits were located beneath pillar bases (Soediman 1976), ${ }^{133}$ while at Dwarawati the bronze bowls had been placed along the inner wall of the cella, some $80 \mathrm{~cm}$ below the pavement (Anom 1985). ${ }^{134}$

If we now turn to Indian texts, we observe that they offer two alternatives for the location of the garbhabhajana (consecration deposit box), depending on their geographical origin (Ślączka 2007: 192-193). ${ }^{135}$ South Indian texts mention only one consecration deposit and prescribe it to be installed south/ right of the doorway. The casket must be either round or square, preferably made from metal, ${ }^{136}$ and must count 9 or 25 compartments. On the other hand, the only three North Indian texts ${ }^{137}$ dealing with garbhanyāsa emphasise the importance of the centre. They mention either one central casket, or nine deposits - a central offering surrounded by eight secondary deposits. These texts do not give many details pertaining to the containers, but they usually qualify them of kalaśa (pitcher, waterpot). Only the central pitcher would be accompanied by a garbhabhajana "in the form of a lotus". ${ }^{138}$ Interestingly enough, whereas many authors have emphasised the South

Prambanan's secondary shrine no. 35 (outer row, northern side) was being dismantled, the restoration workers discovered 10 rectangular stone slabs $(c a .40 \times 20 \mathrm{~cm})$ with a small square cavity and a lid (Wijaya Kusuma 2016).

132. We have mentioned here only those found in Hindu context. Note that two sets of peripih boxes, respectively found at Candi Plaosan and Sojiwan, suggest that the ritual was slightly different in Buddhist context. At Plaosan Lor, four stone caskets with lids were discovered in the foundation pit, beneath the central chamber of the northern twin temple. They were placed roughly plumb of the inner corners of the cella. The southeast peripih box contained a bronze vase, seeds, a mirror, strips of gold, silver and bronze, as well as an inscription. The northeast and southwest ones enclosed only fragments of gold and bronze. The northwest casket was empty. About the Plaosan Lor peripih, see Gutomo \& Niken Wirasanti 1998: 53-55.

Five peripih boxes were discovered in 2012 during restoration work at Candi Sojiwan. They were discovered below the stüpa north of the main temple, at about $2 \mathrm{~m}$ below the modern ground level. These deposits consisted of five plain stone boxes, one in the centre and one in each cardinal direction. Two of the caskets were found with their lid open and had possibly been plundered. The three remaining ones still had their lid on but contained nothing but soil (Photo archive BPCB Jawa Tengah).

133. A cubical space had been left beneath all twelve bases surrounding the cella. However, the temple had already been looted and only five or six of these cavities still contained a peripih - bronze bowls, jars and metal fragments, including a small 9th-century gold inscription (Soediman 1976).

134. Anom mentions that two additional bowls were found during restoration works in 1955 (Anom 1985: 369). One would have been placed at the top of the door jamb, the second below the ambang pintu - an expression that translates either as doorsill or lintel. On the photograph OD-20093, one can however see that the two bronze bowls were placed in small cavities created in the stones from the upper part of the doorjambs, probably right below the lintel.

135. See for example Ajitāgama (4.2; 17.3), Marīcisamhitā (13.1) and Mayamata (12.41-43) as against Agnipurāṇa (41) and Hayaśírșapañcarātrapurāna (12.1-7). See respectively Bhatt 1964; Colas 1986; Dagens 1970; Shastri, Bhatt \& Gangadharan 1998; Raddock 2011.

136. Only the Kämikagāma (31.13) seems to mention stone as an acceptable material.

137. Agnipurāṇa, Hayaśīișapañcarātrapurāṇa and Viśvakarmavāstuśāstram.

138. Agnipurāna 41.21; Hayaśírșapañcarātrapurāna 12.20. 
Indian influence on the Hindu architecture of Central Java, ${ }^{139}$ the peripihs of Candi Kimpulan show affinities with the rituals described in North Indian literature. The presence of a casket at the centre and pots in peripheral points broadly fits the prescriptions of the Hayasírșapañcarātrapurāna. So does the description of the central deposit as having the shape of a lotus. ${ }^{140}$

If we look at the offerings themselves, it is more difficult to detect any agreement between the Kimpulan discoveries and Indian texts. The latter describe at great length the contents of the deposits, which usually include metals, (semi-)precious stones, grains, colouring substances and divine attributes. The variety of items to be placed - either in or around the casket is much wider in the texts than at Candi Kimpulan. According to Indian sources, the casket should contain at least five different metals - gold, silver, copper, iron and tin. ${ }^{141}$ We find only four metals at Kimpulan, namely gold, silver, copper and iron. ${ }^{142}$ And whereas many (semi-)precious stones such as diamond, topaz and sapphire are mentioned in the Sanskrit literature, ${ }^{143}$ Candi Kimpulan has yielded only glass beads and cabochons. ${ }^{144}$ It may be that these gem-like items, with their shiny colours, were used as a replacement for actual precious stones. Of the eight types of grains from the texts, two have been recovered from the excavations of Candi Kimpulan: rice and, possibly, millet. ${ }^{145}$ No traces of colouring substances nor representations of godly attributes have been found at Kimpulan. So, while the general idea of symbolically depositing the riches of the earth is respected, there is no exact correspondence between the texts and the peripih discovered at Candi Kimpulan. The most striking difference probably lies in the fact that the Kimpulan offerings are bulk deposits, while most of the Indian texts insist on the necessity to place each offering in a specific location. ${ }^{146}$ Furthermore, we are left with the question as of why the stone casket from the main temple was found empty. We should underline that the peripih was discovered in its original state; it could not have been looted. Anyhow, the case is not unique.

139. See for example Krom 1923: 137-141; Chihara 1996: 97-107; Dumarçay 1993: 57; Romain: 2011.

140. There are many other examples of stone caskets with 9 or 17 lotus-shaped cavities from Central Java. Unfortunately, most of them have been found out of archaeological context, with the exception of those discovered at the centre of Candi Kimpulan, Ngempon and Payak. Simple stone boxes - with a single large cavity - were found in a similar position at Candi Gatak and Kadisoka. 141. Hayaśîrș̣apañcarätrapurāna (12.18). The Mayamata (41.23-25) adds lead and mercury to this list. The Käśyapaśilpa mentions gold, silver, copper, iron, tin, lead, brass and bell-metal (Ślączka 2007: 102-103).

142. They were placed outside the casket at the main temple, inside the casket at the secondary temple.

143. Diamond, topaz and sapphire seem to be the most commonly found. The texts usually mention nine gemstones, but the list vary from one source to another. The Hayaśîrșapañcarātrapurāna (12.15-16), for example, lists diamond, topaz and sapphire, but also ruby, crystal, conch shell, moonstone and lapis lazuli. In the Käśyapaśilpa (Ślączka 2007: 99-101), the latter two gemstones are not mentioned. Instead, we find sunstone, cat's eye and pearl.

144. All found outside of the casket, except for one brown cabochon discovered within the stone box of the secondary temple.

145. The identification of the second cereal as millet is provisional and still awaits confirmation. 146. The Hayaśīrșapañcarātrapurāna (12.31), for example, recommends placing gold to the east, silver to the south, iron to the west and lead to the north. 
The secondary deposits found at Candi Dwarawati - as well as most of those discovered within the walls of Candi Wisnu (Prambanan) - were also empty. Or, more exactly, filled with sand/earth. Nevertheless, the beginning of an answer might still be found in the texts. One of the first offerings listed in textual sources is earth. Soil samples taken from 8-10 different locations ${ }^{147}$ were indeed supposed to be placed in the garbhabhäjana. ${ }^{148}$ A petrographic analysis of the filling of the Kimpulan deposit box might have brought some clues to confirm this hypothesis but, unfortunately, this point escaped our attention during the excavations so that no samples were collected.

With so few other peripihs found intact, it is impossible to determine the extent to which the deposits of Candi Kimpulan are representative of Central Javanese rituals in general. The only objects from Kimpulan that may qualify as divine attributes are the lotus flowers - one from the linga deposit, the other from beneath the Ganeśa. It is obvious, however, on the basis of museum collections, that the Central Javanese iconographic repertoire was more diverse and that certain peripihs included gold representations of tortoises, snakes, elephants, etc. It is worth noting that these objects do not coincide with any list known from Indian texts. Besides, the item most commonly found on Java - a lotus made of gold - is absent from most published textual sources, with the exception of the Guhyasütra of the Niśvāsatattvasamhitā (2.110) and the Hayaśîrșapañcarātrapurāṇa (12.18) (Goodall 2017: 53; Raddock 2001: 179). The latter, although a Vaiṣnava work, provides useful insights to understand the broad meaning of Central Javanese rituals. As does the Agnipurāna, this text insists on the fact that the central deposit is meant as an invocation of the earth goddess. During the consecration ritual, the officiant must visualise the entire globe and sacrifice to the "eight guardians of the quarters of the world (...) to the rivers, oceans and tirthas and also to the mountains and to the deep lakes and to the ganas, to the lower regions as well, to the bulls and to the elephants who guard and preside over the eight cardinal points, and to the snakes" (12. 35-37) (Raddock 2011: 181-182). The offerings placed in the casket should logically be connected with this invocation of Prthvi; hence the lotus and the tortoise, the bull, elephant and snake found in Central Javanese peripihs. Our understanding is that Central Javanese ritual deposit boxes often contain three types of offerings: a) riches of the earth (grains, seeds, stones etc.); b) symbolical references to the earth and the cosmos; and c) divine attributes (usually of Śiva). Hence, in a stone casket discovered beneath the cella of a shrine at Gedong Songo, were found: a) fragments of crystal and obsidian, glass beads, stone cabochons, bronze pieces and

147. There are some variations. They usually include earth taken from a river, an ant-hill, a crab-hole, the tusk of an elephant and the horn of a bull. According to the Käśyapaśilpa (Ślączka 2007: 123-124), the additional samples must be taken from a pond, a field and a plough-share; from the ocean, a mountain and a field in the Marīcisamhitā (13); from a pond, a field, a mountain and a plough in the Mayamata; from an ocean, a mountain, a lake, a tìrtha and a granary in the Hayaśīrșapañcarātrapurāna (12.10-12).

148. In the Käśsapaśilpa (Ślączka 2007: 125), they are supposed to be placed directly in the garbha-pit. 
gold strips ${ }^{149} \mathrm{~b}$ ) gold leaves engraved with schematic drawings of tortoises, elephant, snake, lotus, circle and square; ${ }^{150} \mathrm{c}$ ) a small linga-yoni made from silver and a gold leaf (fig. 30) and a triśūla.

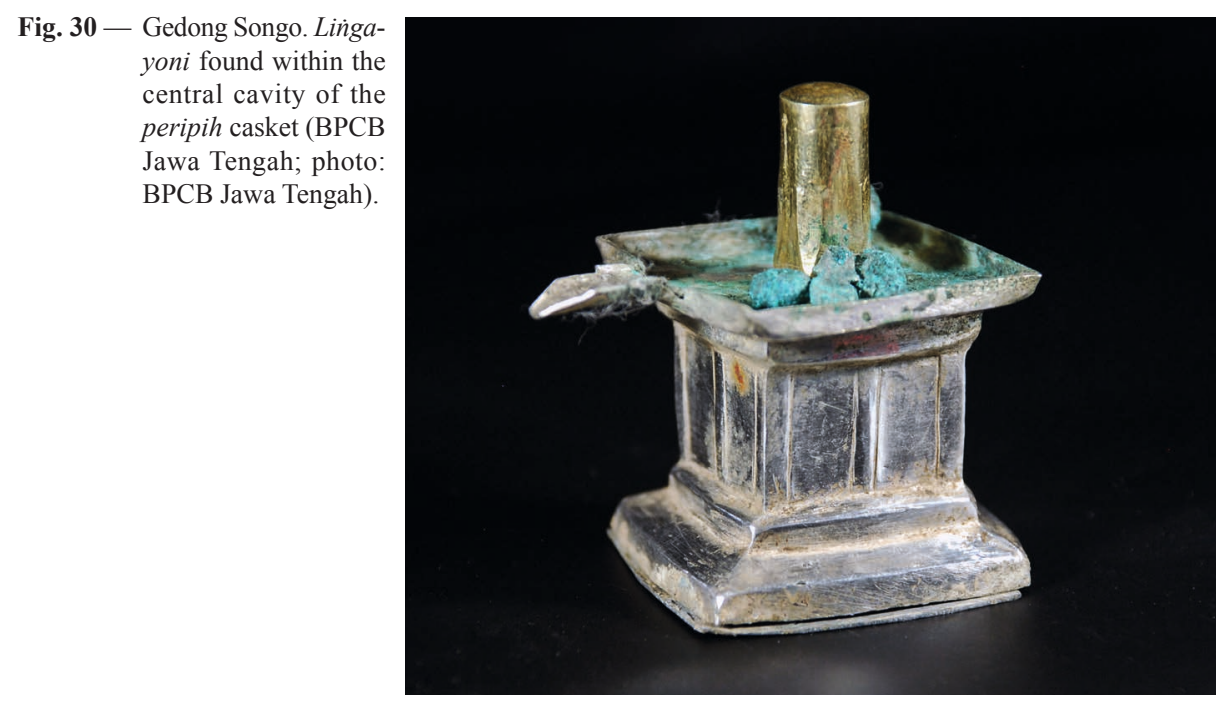

\section{Abandonment and burying process of Candi Kimpulan}

Before concluding this paper, we would like to add a few words about the abandonment and the burying process of Candi Kimpulan. The temple, we have said, was buried under several metres of volcanic materials. It was however not the result of a single large-scale event but, rather, a succession of lahars and riverine sediments. The first lahar resulted in a deposit $c a .1 .2 \mathrm{~m}$ thick of sand mixed with gravels and pebbles, burying the temple base but leaving the upper part of the linga-yoni pedestal and that of Ganeśa statue exposed. The flow must not have hit the temple with great strength, as it did not shatter the building, nor knocked down the pot placed under the yoni's spout (fig. 12). The wooden superstructure seems to have resisted this first lahar, but stratigraphic evidence shows that the pillars were subsequently removed, suggesting that there was still an active population centre nearby. The statues, however, were left to their fate. A second lahar reached Kimpulan possibly not long afterwards. The flow carried numerous pebbles and hit the temple wall with enough strength to dislocate the top stones of the northwest corner. It is at this stage that the site was completely buried and permanently deserted. Subsequent lahars and riverine deposits contributed to erasing the temple from people's memory, until it was unearthed in 2009.

149. Silver $m \bar{a}$-coins were found as well. Although they are not per se a blessing of nature, they are also a reference to prosperity and probably belong to this category.

150. The earth is thought to be carried by four elephants standing on a tortoise. The snake is either a reference to the underworld or to Śeșa - or both. The lotus possibly refers to the earth and the beginning of creation. The circle and the square are symbols of heaven and earth respectively. 


\section{Concluding remarks}

Central Java has yielded relatively few written documents that can be used to retrace its religious history. In this situation, Indian texts have rightly been called upon to fill the gaps and throw light on Javanese religious thought and practice. We nevertheless believe that archaeology is an essential tool to write a history of the religions of Java. Even though it is often challenging - and sometimes impossible - to infer meaning from an object, archaeological remains offer a useful insight into religion as it was practised. Candi Kimpulan reflects a localised religion and the practices of a rural community in the 9th century.

In its temple, the Kimpulan community - or the temple's patron(s) chose not to represent the common Javanese triad. The absence of Durgā and Agastya strengthens the focus on the Siva-Ganeśa duo. The late installation of an irregular stone acting as an altar in front of the Ganeśa statue suggests that local practices revolved more and more around the elephant god. On another note, a deviation from the Javanese tradition and a shift of focus away from Indian textual sources transpires in the shape of the linga, which misses the Viṣnu element. Not only does Śiva prevail, but the qualities associated with Viṣṇu/Durgā and Brahmā/Agastya have become invisible.

If we look at the architecture from an experiential point of view, we will notice that the narrow doorways and small inner space strongly restricted the access to the temple. The distance between the parapet and stone in front of the Ganeśa, for example, is of $c a .50 \mathrm{~cm}$, which is not enough to sit at all comfortably. It is thus highly probable that, as in India, only priests - and, on certain occasions, the elite - were allowed inside. The boundaries between the inside and the outside are clearly marked, and the temple wall is too high for someone standing in the courtyard clearly to observe rituals taking place inside. But the parapet is low enough to allow a glimpse at priests coming and going, standing and bowing. This semi closed architecture created a sort of shadow play and participated to stage the rituals, strengthening the priest's social position.

Material remains of the ratnanyāsa and garbhanyāsa show that the spirit of these rituals was kept, but not the letter. The Kimpulan rituals seem to have been a simpler version of those described in Indian texts. Of course, it could be objected that we may not have consulted the appropriate texts - or that these texts have not been preserved. But it seems more likely that the highly complex rituals described in the normative texts represent an idealised version of religious practice, rituals as they should be according to the Brahman elites, not as they actually took place. The Kimpulan offerings represent first and foremost the riches of the earth. Reference to a mandala inhabited by specific deities seems to be absent. The grains and the treasures from the underworld are deemed enough to draw the life-breath into the building and its statues. While the compartmented caskets fit with the South Indian tradition, the places where peripih were found point towards a North Indian connection. Accordingly, we are under the impression that, like their Buddhist counterparts, Hindu elites from Java were in contact with a wide range of Indian religious centres and incorporated traditions from various horizons into their own culture. 


\section{References}

ANOM, I.G.N.

1985 "Temuan Mangkuk Perunggu Pada Candi Dwarawati", in PusAT Penelitian Arkeologi Nasional, Pertemuan Ilmiah Arkeologi III (PIA III). Ciloto, 23-28 Mei 1983, Jakarta, Proyek Penelitian Purbakala Jakarta, pp. 364-381.

Ari Setyastuti \& Indung Panca Putra (eds.)

2011 Harmoni. Pembangunan dan Pelestarian Candi Kimpulan, Yogyakarta, Balai Pelestarian Peninggalan Purbakala Yogyakarta.

Balai Pelestarian Peninggalan Purbakala Yogyakarta

s.d. Pelestarian Candi Kimpulan. Mengungkap Kembali Warisan Budaya Yang Terkubur, Yogyakarta, Balai Pelestarian Peninggalan Purbakala Yogyakarta.

BAptiste, Pierre

2003 "Le piédestal de Van Trac Hoa: un bali-pītha d'un type inédit. Note concernant l'iconographie des dikpāla au Champa", Arts Asiatiques 58, pp. 168-176.

BARAZER-Billoret, Marie-Luce

1993-1994 "L'installation des linga et des images dans les temples selon les àgama śivaïtes", Bulletin d'études indiennes 11-12, pp. 39-69.

BHATT, N.R.

1964 Ajitāgama, vol. I, Pondichéry, Institut français d'indologie (Publications de l'Institut français d'indologie 24).

Bosch, Frederik David Kan

1915 "Inventaris der Hindoe-oudheden op den grondslag van Dr. R.D.M. Verbeek's Oudheden van Java. Tweede deel", Rapporten van den Oudheidkundigen Dienst in NederlandschIndië, pp. 1-376.

1927 "Oudheidkundig Verslag over het eerste en tweede kwartaal 1927", in Oudheidkundig Verslag, pp. 3-35.

BRUNNER, Hélène

1993 "The Sexual Aspect of the Linga Cult According to the Saiddhāntika Scriptures", in Gerhard OBerhammer (ed.), Studies in Hinduism II. Miscellanea to the Phenomenon of Tantras, Wien, Österreichische Akademie de Wissenschaften (Beiträge zur Kultur- und Geistesgeschichte Asiens 28), pp. 87-103.

Burgess, James

1874 Report on the first season's operations in the Belgâm and Kaladgi districts, London, Archaeological Survey of Western India.

ChiHara, Daigoro

1996 Hindu-Buddhist Architecture in Southeast Asia, Leiden, Brill (Studies in Asian Art and Archaeology 19).

Colas, Gérard

1986 Le temple selon Marīci. Extraits de la Marīcisamhitā étudiés, édités et traduits, Pondichéry, Institut français d'indologie (Publications de l'Institut français d'indologie 71). 
Daftar Peninggalan Benda DIY

1985 Daftar Peninggalan Sejarah dan Purbakala Benda Bergerak di Propinsi Daereah Istimewa Yogyakarta, Bogem, Suaka Peninggalan Sejarah dan Purbakala Yogyakarta [unpublished report].

DAGENS, Bruno

1970 Mayamata. Traité sanskrit d'architecture, Première partie, Pondichéry, Institut français d'indologie (Publications de l'Institut français d'indologie 40.1).

1976 Mayamata. Traité sanskrit d'architecture, Deuxième partie, Pondichéry, Institut français d'indologie (Publications de l'Institut français d'indologie 40.2).

Degroot, Véronique

2009 Candi, Space and Landscape. A study on the distribution, orientation and spatial organization of Central Javanese temple remains, Leiden, Sidestone Press (Mededelingen van het Rijksmuseum voor Volkenkunde 38).

Degroot, Véronique, Arlo Griffiths \& Baskoro TJahjono

2010-2011 "Les pierres cylindriques inscrites du Candi Gunung Sari (Java Centre, Indonésie) et les noms des directions de l'espace en vieux javanais", Bulletin de l'École française d'ExtrêmeOrient 97-98, pp. 367-390.

Degroot, Véronique \& Marijke J. Klokke

2010 "Interrelationships of Central Javanese temple remains: the example of Asu, Lumbung, and Pendem", Archipel 80, pp. 45-76.

DUMARÇAY, Jacques

1973 "Les charpentes rayonnantes sur plan barlong ou carré de l'Asie méridionale", Bulletin de l'École française d'Extrême-Orient 60, pp. 85-104.

1986 Le savoir des maîtres d'œuvre javanais aux XIII e et XIV siècles, Paris, EFEO (Publications de l'École française d'ExtrêmeOrient, Mémoires archéologiques 17).

1993 Histoire de l'architecture de Java, Paris, École française d'Extrême-Orient (Mémoires archéologiques 19).

Edi Sedyawati

1994 Ganeśa statuary of the Kadiri and Sighasāri periods, Leiden, KITLV Press (Verhandelingen van het Koninklijk Instituut voor Taal-, Land- en Volkenkunde 160).

Edi Sedyawati, Hariani Santiko, Hasan Duafar, Ratnaesih Maulana, Wiwin DuUwita Sudjana Ramelan \& Chaidir Ashari

2013 Candi Indonesia. Seri Jawa, Jakarta, Direktorat Pelestarian Cagar Budaya dan Permuseuman.

GRIFFITHS, Arlo

2011 "Imagine Lankapura at Prambanan", in Andrea ACRI, Helen Creese \& Arlo Griffiths (eds.), From Laika Eastwards. The Rāmāyaṇa in the Literature and Visual Arts of Indonesia, Leiden, KITLV Press, pp. 133-148. 
Goodall, Dominic

2017 "On Image-Installation Rites (linga-pratiștha) in the Early Mantramārga", in István Keul (ed.), Consecration Rituals in South Asia, Leiden, Brill (Numen Books Series 155), pp. 45-84. forthcoming Tantrikabhidhanakosa IV: Dictionnaire des termes techniques de la littérature hindoue tantrique. A Dictionary of Technical Terms from Hindu Tantric Literature. Wörterbuch zur Terminologie hinduistischer Tantren, Wien, VÖAW.

Gutomo \& Niken Wirasanti

1998 Purna Pugar Candi Plaosan Lor. Candi Utama Utara, Gapura Utama Halaman I, Candi Patok, Candi Perwara Deret II No 1, Arca Dwarapala, Prambanan, Suaka Peninggalan Sejarah dan Purbakala Propinsi Jawa Tengah [unpublished report].

HoEPERMans, N.W.

1913 "Hindoe-oudheden van Java", Rapporten van den Oudheidkundigen Dienst in Nederlandsch-Indië, pp. 73-371.

KROM, Nicolas Johannes

1923 Inleiding tot de Hindoe-Javaansche kunst, 2nd ed., vol. 1., 's-Gravenhage, Nijhoff.

Machi Suhadi \& Richadiana K.

1996 Laporan Penelitian Epigrafi di Wilayah Provinsi Jawa Timur. Jakarta, Pusat Penelitian Arkeologi Nasional (Berita Penelitian Arkeologi 47).

VAN DER Molen, Willem

2015 H. Kern - Rāmāyaṇa. The story of Rāma and Sìtā in Old Javanese. Romanized edition, Tokyo, Research Institute for Languages and cultures of Asia and Africa, Tokyo University of Foreign Studies (Javanese Studies 1).

NAKADA, Kōzō

1982 An Inventory of the Dated Inscriptions in Java, Tokyo, The Toyo Bunko (The M.T.B. off-prints series 27; Memoirs of the Research Department of the Toyo Bunko 40).

Nelson, L., Nellie Atmosudiro, E. Stickler \& I. Wieser

2005 Ganesha. Javanese Images of the Hindu God of Wisdom and Remover of Obstacles, Jakarta, Indonesian Heritage Society (Museum Nasional Project Series 3).

Pardyanto, L., L.D. Reksowirogo, F.X.S. Mitrohartono

\& S.H. HARDJOWARSITO

1978 Peta Daerah Bahaya Gunung Merapi, Jawa Tengah, Scale: 1: 100.000, Bandung, Direktorat Geologi - Geological Survey of Indonesia.

Perquin, P.J.

1927 “Tjandi Merak”, Oudheidkundig Verslag, pp. 154-188.

Perquin, P.J. \& F.D.K. Bosch

1925 "De oudheden te Palgading", Oudheidkundig Verslag, pp. 61-68. 
RADDOCK, Elizabeth Eva

2011 Listen how the wise one begins construction of a house for Viṣnu: vijānatā yathārabhyaṃ gṛham vaiṣnavaṃ śrṇv evaṃ. Chapters 1-14 of the Hayaśírșa Pañcarātra, Berkeley, California Digital Library, University of California. Retrieved from https://escholarship.org/uc/item/83r393vc.

Romain, Julie

2011 "Indian Architecture in the 'Sanskrit Cosmopolis': The Temples of the Dieng Plateau", in Pierre-Yves Manguin, A. Mani \& Geoff WADE (eds.), Early Interactions between South and Southeast Asia. Reflections on Cross-Cultural Exchange, Singapore, Institute of Southeast Asian Studies (Nalanda-Sriwijaya Series), pp. 299-316.

Riboet Darmosoetopo, Tuahjono Prasodjo \& Rita Margaretha Setianingsih

2015 Pusaka Aksara Yogyakarta. Prasasti Koleksi Balai Pelestarian Cagar Budaya Yogyakarta, 2nd edition, Yogyakarta, Balai Pelestarian Cagar Budaya.

RoBson, Stuart

2015 The Old Javanese Rāmāyaña. A new English Translation with an Introduction and Notes, Tokyo, Research Institute for Languages and cultures of Asia and Africa, Tokyo University of Foreign Studies (Javanese Studies, 2).

SARKAR, Himansu Bhusan

1971 Corpus of the Inscriptions of Java up to 928 A.D., 2 vols. Calcutta, Mukhopadhyay.

Shastri J.L., G.P. Bhatt \& N. Gangadharan

1998 Agni Purāna Unabridged, Delhi, Motilal Banarsidass [reprint of the 1954 edition].

ŚlączKa, Anna Aleksandra

2007 Temple Consecration Rituals in Ancient India. Text and Archaeology, Leiden-Boston, Brill (Brill's Indological Library, 26).

2017 "The Ratnanyāsa (Placing of Gems) Ritual in the Devyāmata, an Early Śaiva Pratișthātantra", in István Keul (ed.), Consecration Rituals in South Asia, Leiden, Brill (Numen Books Series 155), pp. 85-112.

SOEDIMAN

1976 Sepuluh Tahun Ekskavasi Candi Sambisari (1966-1975), Yogyakarta, Yayasan Purbakala.

SOEKMONO

1995 The Javanese Candi. Function and Meaning, Leiden-New YorkKöln, Brill (Studies in Asian Art and Archaeology, 17).

Soenarto, Th. Ag.

1985 "Temuan Periuk Perunggu di Candi Sewu [sic]. Suatu Tambahan Data", in Pusat Penelitian Arkeologi Nasional, Pertemuan Ilmiah Arkeologi III (PIA III). Ciloto, 23-28 Mei 1983, Jakarta, Proyek Penelitian Purbakala Jakarta, pp. 382-389 [about the deposits of Candi Wisnu, Prambanan]. 
Titi Surti Nastiti, Dyah Wujaya Dewi \& Richardiana Kartakusuma

1982 Tiga Prasasti dari Masa Balitung, Jakarta, Pusat Penelitian Arkeologi Nasional.

TJAHJONO PRASODJO

2013 “Ancient history and rediscovery”, in Véronique Degroot, Helly MinARTi (eds.), Magical Prambanan, Jakarta, BAB Publishing Indonesia, pp. 17-23.

VERBEEK, R.D.M.

1891 Oudheden van Java. Lijst der voornaamste overblijfselen uit den hindoetijd op Java met eene oudheidkundige kaart, 's-Gravenhage, Nijhoff/ Batavia, Landsdrukkerij.

WiJAYA Kusuma

2016 "10 Peripih Ditemukan di Candi Perwara di Kompleks Prambanan", Kompas.com - 08/03/2016 (last accessed on 05/06/2018).

WiLLIS, Michael

2009 The Archaeology of Hindu Ritual. Temples and the establishment of the gods, New York, Cambridge University Press. 